\title{
Insulin resistance in diabetes: the promise of using induced pluripotent stem cell technology
}

\author{
Ahmed K. Elsayed ${ }^{1}$, Selvaraj Vimalraj ${ }^{2}$, Manjula Nandakumar ${ }^{1}$, Essam M. Abdelalim ${ }^{1,3^{*}}$ \\ ${ }^{1}$ Diabetes Research Center, Qatar Biomedical Research Institute (QBRI), Hamad Bin Khalifa \\ University (HBKU), Qatar Foundation (QF), PO Box 34110, Doha, Qatar. \\ ${ }^{2}$ Centre for Biotechnology, Anna University, Chennai, 600025, Tamil Nadu, India. \\ ${ }^{3}$ College of Health and Life Sciences, Hamad Bin Khalifa University (HBKU), Qatar Foundation, Education City, \\ Doha, Qatar.
}

* Correspondence: e-mail: emohamed@hbku.edu.qa; Tel.: +974-44546432 / Fax: +974-44541770

\begin{abstract}
In this review, we discuss the insulin resistance (IR) and its development in the insulin target tissues that leads to diabetes. Also, we highlight the use of induced pluripotent stem cells (iPSCs) to understand the mechanisms underlying the development of IR. IR is associated with several metabolic disorders, including type 2 diabetes (T2D). The development of IR in insulin target tissues involves genetic and acquired factors. Persons at genetic risk for T2D tend to develop IR several years before glucose intolerance. Although there are currently several mouse models for both IR and T2D that had provided a lot of information about the disease, these models cannot recapitulate all the aspects of this complex disease as seen in each individual. Patient-specific iPSCs can overcome the hurdles faced with the classical mouse models for studying IR. iPSC technology can generate cells genetically identical to IR individuals, which can help in distinguishing between genetic and acquired defects in insulin sensitivity. Combining the technologies of the genome editing and iPSCs may provide important information about the inherited factors underlying the development of different forms of IR. Further studies are required to fill the gaps in understanding the pathogenesis of IR and diabetes.
\end{abstract}

Keywords: Type 2 diabetes. insulin target tissues. iPSCs. genetic factors. disease modeling

\section{Introduction}

Insulin resistance (IR) is a hallmark of type 2 diabetes (T2D) and other related metabolic disorders. Several hereditary and environmental factors are known to be involved in the development of IR in individuals at risk for T2D. Persons at genetic risk for T2D tend to develop IR several years before glucose intolerance [1,2]. Diabetes is associated with several complications, such as diabetic ketoacidosis, nonketotic hyperosmolar coma or death, heart disease, stroke, kidney failure, foot ulcers etc. Glucose metabolism is regulated by a feedback loop between islet $\beta$-cell and insulin -target tissues. Under IR condition, the $\beta$-cells control normal glucose tolerance by increasing the level of insulin secretion $[3,4]$.

IR in different tissues (adipose tissue, skeletal muscle, liver, brain, gut, pancreas, vasculature and kidney) and their cross talks leads to several metabolic disorders, including T2D, cardiovascular diseases, hypertension, polycystic ovary syndrome (PCOS), fatty infiltration of the liver (non-alcoholic fatty liver disease (NAFLD), apnea, a sleep disorder, arthritis, skin diseases, and cancers. Previous studies showed alterations in the gene expression prolife between the individuals with family history of T2D and those without family history of the disease. Those defects were mainly observed in the genes related to mitochondrial function and fat metabolism [5-7]. However, it is difficult to distinguish between whether the alterations in the gene profiles are due to genetic or environmental factors. 
Although, several genetic and environmental factors are known to be involved in the development of IR, the molecular and cellular mechanisms underlying IR development and its progression to T2D remain not completely understood. This is due to lack of the appropriate human models to study the pathophysiology of different forms of IR. Induced pluripotent stem cell (iPSC) technology offers new tools to study the genetic factors involved in the development of human diseases. Therefore, iPSCs provide a source to be used as human model to study the IR in insulin target tissues and pancreatic $\beta$ cell dysfunction [8]. iPSCs can generate cells genetically identical to insulin resistant individuals, which can help in distinguishing between genetic and acquired defects in insulin sensitivity. In the current review, we mainly focus on the IR associated with diabetes and the mechanism involved. Also, we discuss the use of iPSC technology to understand and treat these disorders and explain the challenges and limitations of using the human iPSC-based models.

\section{INSULIN SIGNALING AND ITS PHYSIOLOGICAL ROLE}

Insulin is an anabolic polypeptide hormone synthetized in pancreatic $\beta$-cells as a pre-proinsulin and stored in its secretory vesicles as an immature proinsulin, which secreted into portal vein as mature insulin and c-peptide $[9,10]$. This hormone plays a critical role in a wide range of cells and tissues in the body through its main action in regulating the cellular energy supply and metabolic processes of the macronutrients (carbohydrate, protein, and lipid) in addition to its growth promoting action through its mitogenic effect. These basal requirements for every individual tissue indicate the great necessity of insulin as any impairment in insulin can influence on the functionality of most organs and affecting the normal physiology of the whole body.

On the cellular level, the insulin actions and effects on the target tissues achieved through its signaling pathway starting from its binding to insulin receptor which activate the downstream intra-cellular molecules that express the insulin action either metabolic or mitogenic (Fig. 1). The metabolic effect of insulin is anabolic as it promotes the glycogen, lipid and protein synthesis as well as inhibiting the gluconeogenesis and lipolysis [11]. It also facilitates the intracellular glucose uptake through translocation of the insulin dependent glucose transporter (GLUT4) as in skeletal muscle and adipose tissue [12,13]. This metabolic action of insulin is achieved through phosphatidylinositol 3 (PI3K) kinase pathway and its downstream PIPD 1\&2 kinases, protein kinase B (AKt/ PKB) and Protein kinase C (PKC). GLUT4 can be alternately translocated by insulin stimulation through the activated GTP/TC10 complex [14]. Meanwhile, the insulin's growth promoting action is achieved through INSR and insulin growth factor receptor (IGFR), which activate the RAS/ MAP kinase pathways which in turn activate the transcription factors of cell division and proliferation [15].

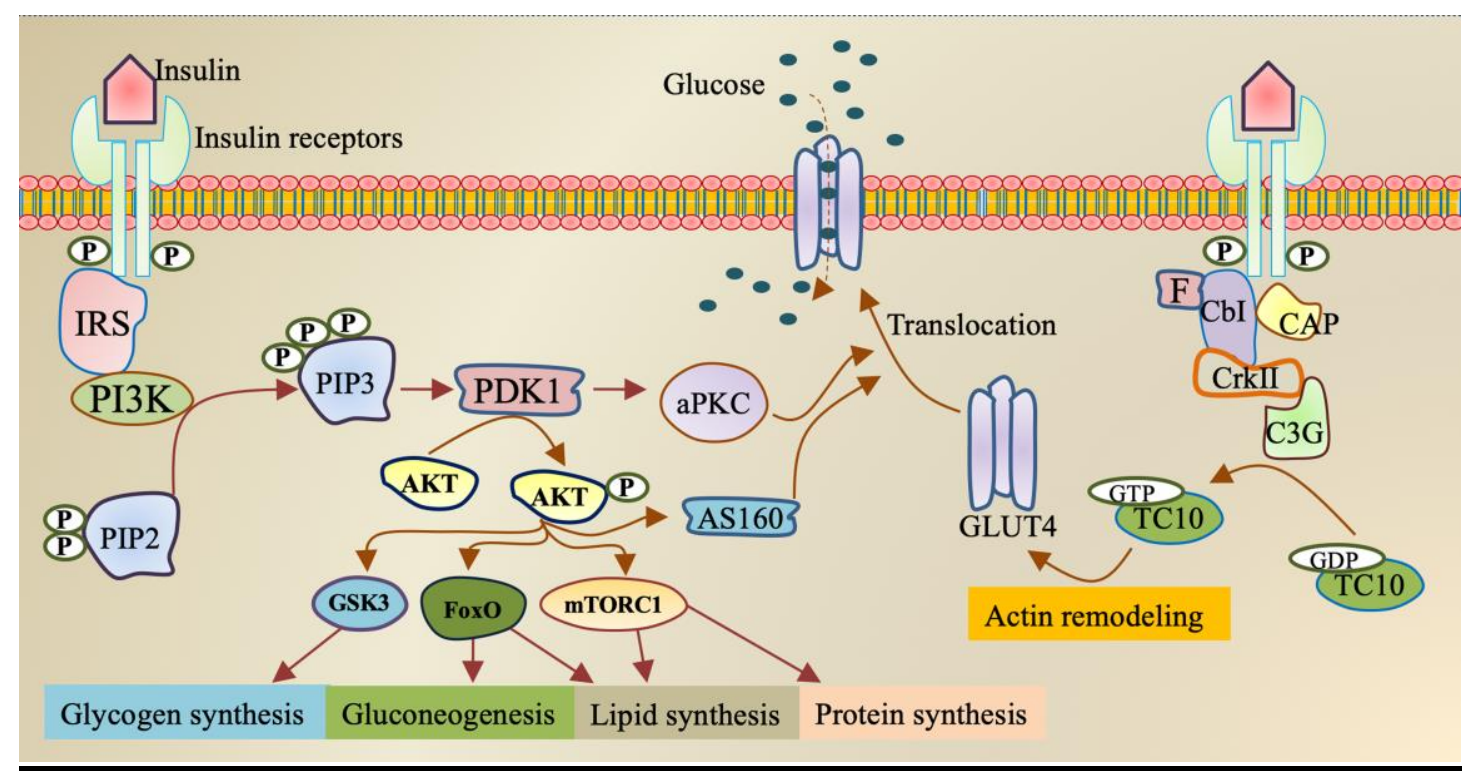


Figure 1. Schematic illustration of insulin signaling pathways. Insulin binding activates the IR, which enables the recruitment of IRS isoforms and subsequent activation of the PI3K. The downstream event of PI3K enhances glucose uptake by translocation of glucose transporter proteins over cell membrane, enhances glycogen, lipid and protein synthesis and regulates lipolysis and gluconeogenesis. Alternative pathway for GLUT-4 translocation by insulin stimulation. Insulin binding activates the IR, which enables F binding to CAP Phosphorylates Cbl and recruit CrkII/C3G complex. This complex converts GDP into GTP on TC10. The stimulated GTP containing TC10 involved in GLUT-4 translocation by actin remodeling on GLUT-4. Insulin receptor (INSR), Insulin receptor substrate (IRS), phosphatidylinositol 3-kinase (PI3K), phosphatidylinositol 4,5 bisphosphate (PIP2), phosphatidylinositol 3,4,5 trisphosphate (PIP3), phosphatidylinositidedependent protein kinase 1 (PDK1), atypical protein kinase $\mathrm{C}$ (aPKC), glycogen synthase kinase 3 (GSK3), forkhead box O (FoxO), mTOR complex (mTORC), Akt substrate 160kDa (AS160), Flotillin (F), Cbl associated protein (CAP). CRK proto-oncogene, adaptor protein (CRK), transcript variant II (CrkII). Guanine nucleotide exchange factor (C3G), guanosine triphosphate (GTP), guanosine diphosphate (GDP), small GTP binding protein TC10 (TC10), Glucose transporter type 4 (GLUT-4).

\section{INSULIN RESISTANCE AND ITS CONSEQUENCES}

IR is the condition in which the cells respond inappropriately to the circulating insulin. In other terms it is the impaired sensitivity to insulin-mediated actions [16]. It is known that insulin controls the energy production to be mainly through glucose oxidation and inhibiting the other sources such as lipolysis, protein catabolism, glycogenolysis and gluconeogenesis. However, in case of IR, these processes directed to be activated as an alternative source of energy to glucose. These catabolic processes are accompanied by accumulation of toxic metabolic byproducts and inflammatory factors, which have harmful effects on the insulin-target tissues. The muscular glycogen and protein synthesis is impaired with decrease in glucose uptake leading to sarcopenia [15].

Under IR conditions, the lipolysis is enhanced leading to the release of triglyceride, free fatty acids (FFAs) and inflammatory cytokines (e.g. IL-6, TNF $\alpha$, Leptin) into the circulation [17]. The metabolic toxic derivatives of FFAs and the inflammatory cytokines affect the functionality of most other tissues either directly through its lipo-toxic and lipo-apoptotic effects or indirectly through impairment in the insulin signaling pathways [18-20]. The liver responds to IR and the demand of other cells to glucose by stimulation of the glycogenolysis process and so more glucose output [21,22]. The released FFAs from fat (due to IR) transported to liver causes nonalcoholic fatty liver disease (NAFLD) (Steatohepatitis), which is subsequently followed by liver cirrhosis [23]. This impairment in the liver function leads to decrease in the insulin clearance with hyperinsulinemia. IR induces the impaired mitochondrial oxidative metabolism and the endocrine disorders like polycystic ovary syndrome (PCOS), adrenal disorders and thyroid function abnormalities [24,25]. It has been discussed that the insulin sensitive brain areas are hypothalamus, prefrontal cortex, hippocampus and fusiform gyrus. So the IR in brain cause mild cognitive impairment (MCI) and dementia and Alzheimer's disease [26,27]. IR in gut leads to alteration in microbiota thereby resulting in dysregulated short chain fatty acid (SCFAs) production and dysregulated gut hormone production $[18,28]$.

\section{INSULIN RESISTANCE AND TYPE 2 DIABETES (T2D)}

Impairment in glucose homeostasis that regulated by the feedback loop between the insulin target tissues and the pancreatic insulin producing $\beta$ cell, is the main cause of diabetes mellitus. In other words, the diabetes mellitus is considered as the end stage of chronic disorders caused by IR in the insulin target tissues, which lead to more increase in blood glucose and finally impair the $\beta$-cell function (Fig. 2). IR and decreased insulin synthesis and eventual pancreatic $\beta$-cell failure are the major characteristic features of T2D pathological condition. IR leads to hyperinsulinemia, which may play an important role in these abnormalities. There is an increase in the breakdown of fat with hyperglycemia, which impairs pancreatic $\beta$-cell insulin production and aggravates IR. Increased FFA concentrations, inflammatory cytokines from adipose tissue, oxidative factors and differentially expressed genes have been accountable in the pathogenesis of T2D and their accompanied metabolic disorders. 
Impairment in insulin sensitivity in skeletal muscle, adipose tissue and liver are mainly responsible for the IR progression in the entire body and are the precursor of T2D and other metabolic disorders. The relation between the IR in these tissues and its link to T2D is discussed below.

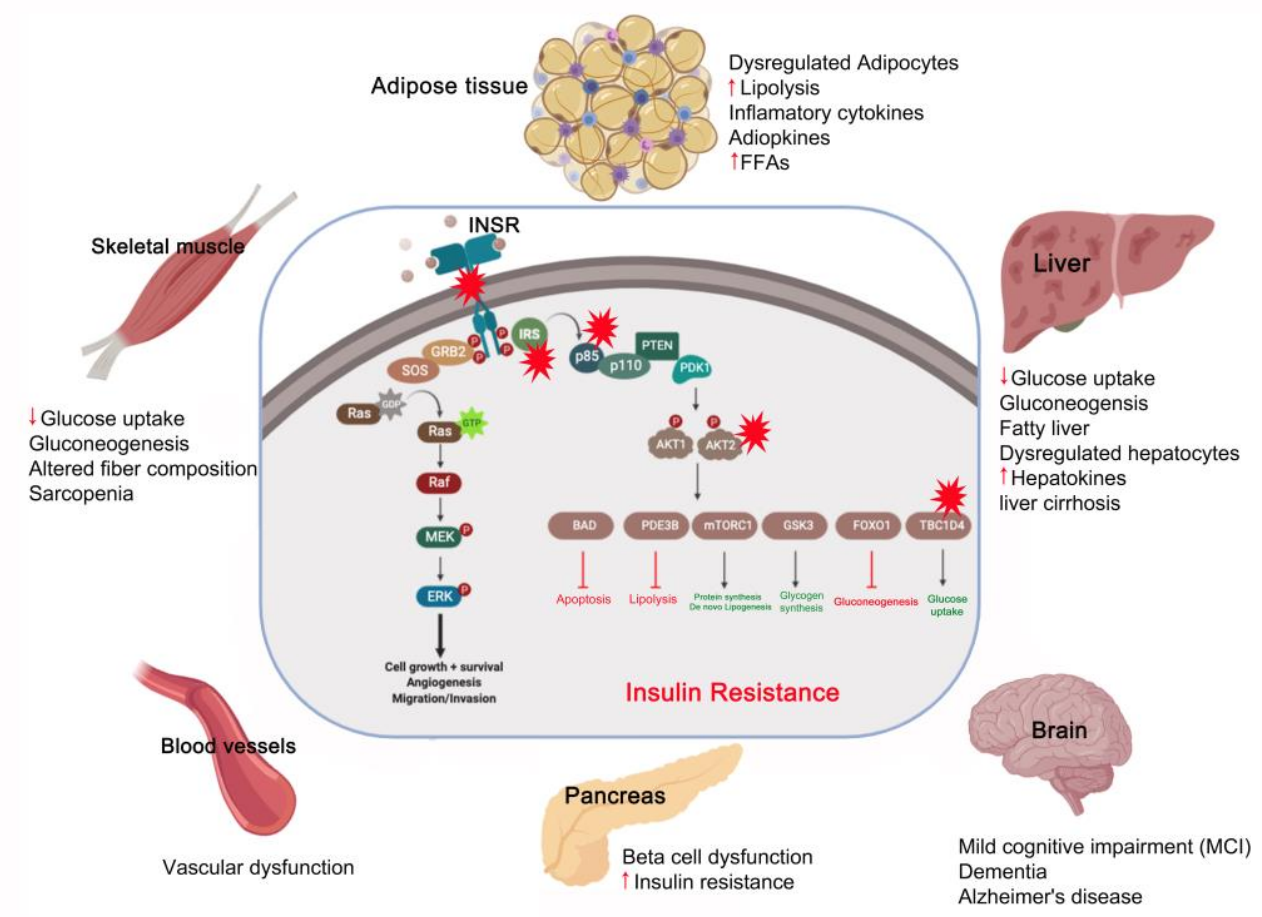

Figure 2. The pathological effect and consequence of insulin resistance (IR). Genetic alterations and mutations in the insulin signaling pathway can lead to IR in the insulin-target tissues. The red stars indicate the reported genetically defective molecules, such as insulin receptor (INS), insulin receptor substrates (IRS), p85, AKT and TBC1D4. In response to insulin resistance, the insulin target tissues (adipose tissue, skeletal muscle, liver, pancreas, brain and blood vessels) show activation of the catabolic processes and accumulation of toxic metabolic byproducts and the inflammatory cytokines, leading to pancreatic $\beta$-cell dysfunction and other metabolic disorders.

\section{Skeletal Muscles}

IR in the skeletal muscle is one of the main defects, which appears several years before the development of $\beta$-cell dysfunction and hyperglycemia $[29,30]$. The molecular and genetic basis for the development of IR in the skeletal muscle is not fully understood. In human, skeletal muscle is considered as the primary site of glucose uptake ( $\sim 80 \%$ take place in the skeletal muscle) [31]. The main defect responsible for the IR during the early stages of T2D development is the impairment in the glycogen synthesis in skeletal muscle. Previous studies used muscle biopsies showed that the mitochondrial DNA, mitochondrial genes, and respiratory chain subunits proteins are downregulated in IR subjects in comparison to healthy controls [32,33]. Another study showed that cultured myoblasts isolated from skeletal muscle of T2D patients have defects in glucose transport and insulin signaling [34]. In the skeletal muscle of the insulin resistant offspring of T2D parents, it has been found that the mitochondrial ATP production, mitochondrial density, and AKT activation are significantly reduced, while the IRS-1 phosphorylation (serine) is significantly increased [32,35]. The activation of PI3K pathway is required for transport of glucose and synthesis of glycogen, which are impaired after insulin stimulation in insulin resistant skeletal muscle [36,37]. The upregulation of IRS-1 phosphorylation on serine residues has been found to suppress insulin signaling in T2D [35]. Furthermore, the hiPSCderived myotubes generated from patients with INSR mutation stimulated with insulin didn't increase glucose uptake, glycogen synthase activity, or glycogen stores, suggesting impairment in insulin signaling as a result of INSR mutation [38]. Taken together, these findings indicate that the defects in 
the insulin signaling, glucose transport, glycogen synthesis, and mitochondrial activity are main dysfunctional features associated with the IR in the skeletal muscle.

\section{Adipocytes}

Adipose tissue is considered the main regulator of insulin action in the body; therefore, defects in insulin signaling in adipocytes cause systemic IR, indicating that impairments in adipose insulin signaling are a common hallmark of IR [39]. Molecular dysfunctions of this process, such as defects in insulin-signaling pathway, involving suppression of lipolysis and glucose transport, leads to the development of IR in adipocyte tissues. [40]. Glucose transporter, GLUT4, is significantly downregulated in subcutaneous adipose cells from T2D patients and in healthy individuals with a genetic susceptibility for T2D [41]. This reduction in GLUT4 expression is associated with changes in the secretion of adipokines. Also, activation of peroxisome proliferator activated receptors (PPARs), which are responsible for the regulation of adipogenesis as well as lipid metabolism in adipocytes, leads to an improvement in insulin sensitivity through the induction of the expression of several genes that are related to insulin signaling pathway. In addition to its role in adipogenesis, PPAR is involved in regulating lipid, metabolism in mature adipocytes by increasing fatty acid trapping [42]. The importance of insulin signaling in the development of adipocyte IR has been reported in T2D, where previous studies reported that the substrate of insulin receptor (IRS-1) is involved in IR in adipocytes by inhibiting insulin-signaling [43]. Also, in T2D patients, several IRS-1 mutations have been found [4446] and a reduced IRS-1 protein level has been observed in adipocytes from other T2D patients [47], relatives of T2D patients, and obese individuals [48]. In addition to insulin signaling defects, dysregulation of adipokines and lipolysis process are linked to IR and T2D. The adiponectin gene is considered a candidate susceptibility gene for T2D, because it has been detected on chromosome 3q27, which is linked to T2D and the metabolic disorders [49-51].

\section{Liver cells}

The insulin signaling in the hepatic cells is crucial in maintaining normal liver function and regulating glucose homeostasis [52]. The liver activates the glucose uptake and glycogen storage, but it inhibits glycogenolysis and gluconeogenesis. Hepatic IR progression plays a critical role in the pathogenesis of T2D. Loss of INSR signaling in hepatic tissue leads to an increase in the gluconeogenesis and a decrease in the lipogenesis [52-54]. The IRS-1/2 is involved in the suppression of gluconeogenesis and stimulation of lipogenesis. In the liver, insulin inhibits IRS-2 expression at the transcriptional level and doesn't influence on IRS-1 expression [53,55]. Hepatic IR characterized by inability of insulin to inhibit the production of glucose in the liver [56]. This impairment in the liver function leads to decrease in the insulin clearance with hyperinsulinemia. The released FFAs from fat tissues due to IR transports to liver causing nonalcoholic fatty liver disease (NAFLD) (Steatohepatitis), which followed by liver cirrhosis [23]. Liver-derived proteins termed as hepatokines are released into the circulation which causes defective insulin signaling [57]. The hepatokine fetuin-A was identified as an endogenous ligand for TLR4 through which saturated fatty acids induce proinflammatory cascade and regulate insulin action [58]. Other than fetuin-A, hepatokines Fibroblast growth factor 21 (FGF21) and Selenoprotein P are major drivers of IR $[59,60]$.

\section{GENETIC FACTORS INVOLVED IN INSULIN RESISTANCE DEVELOPMENT}

The IR arises due to counteracting insulin action or any defect affecting the insulin signaling pathway starting from its receptor (INSR) followed by a series of downstream branching pathways which involve complex cross talks and feedback effect on each other. This complexity widens the variety of IR etiologies from environmental and genetic perspectives. Several factors and effectors are involved in IR including; diet habit, obesity, lifestyle, physical activity, pharmacological agents, drugs, stress, cytokines, hormones and any factor antagonist the insulin action.

In many cases, the familial history and hereditary factors showed the effect of genetic alterations as a risk factors of IR occurrence that will be discussed below. Genetic alteration causing IR may have a 
direct effect on the cellular insulin signaling pathway or indirectly through affecting other targets with subsequent secondary effect on the insulin pathway. The disruption and/or mutations in the genes encoding proteins involved in insulin signal transduction impairs insulin action and reduces rate of glucose uptake leading to IR.

\section{Mutations in INSR and Insulin Signaling Genes}

There are several mutations in the INSR, which have been classified into several classes: class1 (impaired receptor biosynthesis); class II (receptors with impaired processing and trafficking to plasma membrane); class III (decreased affinity to insulin binding); class IV (receptors with defective phosphorylation and kinase activity); and class $\mathrm{V}$ (receptor recycling defects and receptor degradation in lysosome) [61]. There are two types of INSR mutations, autosomal recessive and mild type mutations. The autosomal recessive condition is more severe as it is caused by mutation in both alleles of INSR gene and is usually presented in the infantile and early childhood stage as in Donohue and Rabson Mendenhall syndromes. These syndromes are characterized by an increase in the plasma insulin level with postprandial hyperglycemia in addition to severe growth retardation with poor prognosis history $[62,63]$. The mild form of INSR mutation is caused by mutation in one allele or mutation in the intra cellular domain only of the INSR and is commonly presented around puberty period and is usually accompanied by lipoatrophy and hyperandrogenism [64,65].

Homozygous mutation in INSR (INSR-/-) develops diabetes rapidly and causes lethality within the first week after birth in mice $[66,67]$. Nonsense and deletion mutations have been correlated in INSR and cause IR through decreasing the insulin receptor mRNA level or by deletion of the important domains of INSR [68,69]. Also, INSR mutation might cause the reduction of INSR tyrosine kinase activity [70]. Several mutations and polymorphisms in IRSs, particularly IRS1 and IRS2 have been proved to be involved in IR [71].

Genetic loss-function of the molecule(s) involved in intracellular signal transmitting from phosphorylated INSR impairs insulin signaling leading to development of IR. Several post-receptor genetic defects have been reported. Loss of function and mutation of PI3K showed a severe IR which is common in SHORT syndrome, which is characterized by short stature, joint hyperextensibility and hernias, ocular depression, Rieger anomaly and teething delay [72-74]. A family with mutation in gene encoding for AKT2 inherited with severe IR and diabetes mellitus. R274H mutation disrupted the conformation of the activation and catalytic loops of the enzyme depleting its catalytic activity [75]. In another study, a family with Acantho nigrans was found to possess a heterozygous premature stop mutation in AS160 (TBC1D4), which led to GLUT4 translocation inhibition to the membrane and decrease in the intracellular transportation of glucose and hyperglycemia [76]. TBC1D4 nonsense p. Arg684Ter variant (arginine replaced by a termination codon) was also described with severe insulin resistant case of muscle selective form with, impaired glucose tolerance, T2D and postprandial hyperglycemia and IR [77-81].

\section{Other Mutations Associated with Insulin Resistance}

Other inherited genetic defects affect other tissues or other biological processes may have a secondary action causing IR. There are some complex genetic syndromes associated with IR. Alstrom syndrome, which is autosomal recessive disorder with monogenic form of IR associated with infancy onset obesity, showed mutations in ALMS1 gene with unknown function but it is thought to be involved in intracellular trafficking. A set of missense, nonsense and truncation mutations in ALMS1 were observed in UK cohort [82]. In a case study of familial syndrome of IR, it was observed that members with severe IR were doubly heterozygous frame shift stop mutations in PPARG and PPP1R3A [83] genes that are involved in carbohydrate and lipid metabolism [84]. More heterogenous class of complex monogenic condition exhibiting IR are Werner syndrome [85], Bloom syndrome characterized by premature aging caused by defects in DNA helicases. Another case is of primordial dwarfism caused by mutations in NSMCE.2 [86]. These genes play role in cell division. MDP syndrome is another 
complex syndrome exhibiting severe IR caused by heterozygous mutations in POLD1 encoding DNA polymerase Delta [87].

IR is associated with genetic syndrome linked to lipodystrophy and dyslipidemia. Although, several studies proved that the obesity is a strong predisposing risk factor for IR, the pathogenesis of this process is critically related to adipose tissue defects rather than the obesity degree and adipose tissue capacity. In lipodystrophy, the impaired functionality of the adipose tissue is considered as a sump for flux of free fatty acids into the circulation causing harmful effects, including lipotoxicity and IR. Inherited lipodystrophy is classified according to the degree of adipose tissue loss into; recessive congenital generalized lipodystrophy (CGL) with complete adipose absence and familial partial lipodystrophies (FPLD) with defects in only some parts of adipose tissue [88]. In both types, the clinical cases are associated with fatty liver, hypertriglyceridemia, dyslipidemia and sever IR. CGL is mainly caused by mutation of both allele of either AGPAT2, which is a key factor in the synthesis of triglyceride, or BSCL2 genes, which is important for droplet formation and adipocyte differentiation [89-91]. These two genes mutations represent about $90-95 \%$ of the etiologies of CGL. Defects in other genes as CAV1 and PTRF can lead to CGL through perturbation in small plasma membrane investigation (caveolae) and the disturbance in lipid trafficking [92,93]. In some cases, the genetic alteration in phosphate cytidylyltransferase 1 (PCYT1A) also reported in CGL patients [94]. There are seven mutations in genes regulating the adipocyte biological processes involved in FPLD; LMNA, PPARG, PLN1, CIDEC, PIK3R1, and AKT2 with high incidence in LMNA and PPARG [88]. LMNA is essential in supporting the structural cytoskeleton and protein network surrounding the nuclear envelop; therefore, its mutation alter the gene expression as a result of the defect in the nuclear envelop and abnormal binding of the transcription factor and chromatin in adipose tissue causing lipodystrophy [90]. The LMNA mutant patient lose the adipose subcutaneously in leg and trunk region only with cushingoid topography [95]. PPARG is essential nuclear receptor hormone for adipocyte differentiation and for sensing the flux of fatty acids. The recorded heterozygous PPARG mutation sometimes causes sever dyslipidemia with reduction in the subcutaneous fat [96,97]. Miscellaneous mutation in important lipid droplet proteins (perilipin and CIDEC) that regulate the triglyceride mobilization also implicated in the FPLD [98,99]. Loss of fat droplets and femoro-gluteal adipose tissue is accompanied by severe IR in the primary insulin signaling disorders especially SHORT syndrome and PI3K/AKT mutation where the insulin signaling is very important for adipocyte differentiation causing lipodystrophy in these syndromes $[72,100,101]$.

\section{INSULIN RESISTANCE AND B-CELL DYSFUNCTION}

In T2D, $\beta$-cell dysfunction occurs as a result of IR in the insulin-target tissues [102]. However, the interplay between IR and pancreatic $\beta$-cell dysfunction is still complex (Fig. 2). Many metabolic insults such as obesity, saturated FFA overconsumption, inflammatory cytokines, and oxidative stress and endoplasmic reticulum (ER) stress that decline the functionality of $\beta$-cells, dysregulate the normal physiological state of $\beta$-cells and their exhaustion, leading to their demise [103,104] (Fig. 2). Loss of insulin sensitivity or IR results in hyperglycemia, hyperinsulinemia as well as activation of the catabolic processes, which increase the level of FFAs and lipotoxic cytokines. All of these elevated elements caused by IR are responsible factors for $\beta$-cell stress and dysfunction [105]. In early stages of IR, $\beta$-cells try to compensate and control the glucose homeostasis through production of more insulin [106]. However, with chronic prolonged exposure to hyperglycemia, $\beta$-cells secrete large quantities of insulin, leading to ER stress and exhaustion of $\beta$-cells with depletion of insulin store [107]. Moreover, hyperglycemia for long time lead to decrease in the activity of insulin promotor through reduction in the binding of PDX1 and MAFA with subsequent decrease in insulin gene expression and its secretion $[108,109]$. Hyperglycemia also can induce oxidative stress, inflammation, pro-apoptotic, and apoptotic genes expression in $\beta$-cells $[110,111]$. Elevated plasma level of FFAs and glucose due to IR lead to glucolipotoxicity causing $\beta$-cell failure [112]. These saturated FFAs induce both ER and oxidative stress in human $\beta$-cells and islets through overproduction of NOS2 and NO in $\beta$-cell mitochondria $[107,113-$ $115]$ or through compromising the ER morphology and integrity $[113,114,116]$. In presence of 
hyperglycemia, FFAs influences on the biosynthesis and expression of the insulin gene, leading to suppression of the adequate insulin secretion in response to glucose (GSIS) [108,117-119]. Increased FFAs leads to intrapancreatic and intra $\beta$-cell accumulation of triglyceride and fat droplets, triggering the $\beta$-cell dysfunction and death due to an increase in the inflammation process [120,121]. Inflammation and the proinflammatory cytokines are increasingly being recognized as an important contributor to $\beta$-cell dysfunction [122]. IR associated inflammatory cytokines such as IL6, TNF $\alpha$, IFN $\gamma$, $\mathrm{NF}-\kappa \mathrm{B}$ and others cause the dysfunctionality and death of $\beta$-cells via damage in the mitochondria, cellular proteins, lipids and nucleic acids and ER stress [123-126]. The inflammatory cytokines and the recruited immune cells in the inflamed dysregulated pancreatic islet trigger the $\beta$-cell dysfunction $[127,128]$. Proinflammatory cytokines mediate reactive oxygen species (ROS) and reactive nitrogen species (RNS) production and reduce the ATP production and eventually lead to $\beta$-cell dysfunction [129].

The $\beta$-cell dysfunction and inadequate $\beta$-cell mass expansion can be due to the defect in the insulin signaling pathway in the pancreatic $\beta$-cell itself. Improper glucose sensing has been noticed in mouse $\beta$-cells, which lack the INSR or IGF-1R. Additionally, loss of INSR led to $\beta$-cell mass reduction and early onset diabetes [130-132]. Another study showed similar diabetic phenotypes in mice with PDK1 deficiency in $\beta$-cells [133]. The impairment of cell cycle progression is hypothesized to be engaged in the $\beta$-cell mass reduction and dysfunction. It has been found that the cell cycle inhibitor, p27Kip1, is accumulated in the nucleus of the $\beta$-cells of hyperglycemic IRS2-deficient mice and the deletion of p27Kip1 gene ameliorates $\beta$-cell proliferation and the hyperglycemia, reflecting the role of cell cycle inhibition in the $\beta$-cell function [106,134].

\section{ANIMAL MODELS OF INSULIN RESISTANCE AND THEIR LIMITATIONS}

Although the condition of IR and its complications in human health is well recognized in last three decades, there is no permanent treatment available. It is mainly due to lack of human models to understand the pathophysiological condition of IR and associated diseases. Most of the animal models used to study the IR are derived spontaneously or induced by stress, diet, injuries, chemicals and by different combinations mimicking the IR condition that have been reviewed in details in the previous literatures [135]. Meanwhile, the genetically modified IR animal models (transgenic or knockout) are few [135-137]. The genetic animal models are generated through modification of the genes that are directly involved in the insulin signaling pathway or indirectly through dysregulating the factors causing IR as that involved in obesity and others. IRS knockout mouse model (IRS-/-) showed growth retardation and mild IR, while the heterozygous mutation of INSR and IRS1 model develope acute IR with diabetes within the first 4-6 months of age [138]. Akt2 knockout mouse model showed an impairment in the insulin signaling of the adipocytes and skeletal muscles [139]. GLUT4 +/- null mutant mouse showed a decrease of GLUT4 expression in the insulin-target tissues, which is accompanied by hyperglycemia, hypertension and hyperinsulinemia [138]. On the other hand, GLUT2-/- mice, but not GLUT2+/- develop hyperglycemia and hypoinsulinemia with elevated levels of FFAs [140]. Other animal models exhibit impaired glucose intolerance and IR features with heterozygous knockout of Syntaxin 4 and BDNF (Brain-derived neurotrophic factor), which play an important role in glucose metabolism and body weight [141,142]. Lipodystrophy has shown a strong association with sever IR; therefore, transgenic animals with defects in the genes regulating the fatty acid metabolism used to study IR mechanism [143]. Transgenic mice with overexpression of the adipocyte sterol regulatory element binding protein (SREBP)-1 result in sever diabetes with 60 fold increase of plasma insulin level [144]. Transgenic fatless mouse lacking the white adipose tissue expressing a dominant negative protein (A-ZIP/F-1) develop severe form of IR due to blocking the IRS- dependent activation of PI3K in the liver and muscle [145]. Toll-like receptor 4 (TLR4) knockout mice is used to study the role of TLR4 in the regulation of energy balance and IR [146]. There are several animal models showed the features of the IR and diabetes due to mutations in specific genes either spontaneously or through selective breeding. Leptin $\mathrm{ob} / \mathrm{ob}$ and leptin $\mathrm{db} / \mathrm{db}$ mouse strains develop early hyperglycemia and hyperinsulinemia due to autosomal recessive defects in leptin gene and its receptor, respectively. 
Studies on this model demonstrated the contribution of hepatic tumor factor, NF-kB/RelA, TNF and interleukin4 in the development of IR [147-149]. Zucker fatty (fa/fa) rat exhibit hyperinsulinemia, glucose intolerance and hyperlipidemia due to deficiency in the leptin receptor and autosomal recessive fa gene [150]. Defect in leptin transportation through the blood brain barrier represented in New Zealand mice strain (NZO), which is a hepatic IR model [151]. The spontaneous deletion mutation in CD36 fatty acid transporter gene developed the OLETF rat as a model to study the IR syndrome in hypertensive, hyper insulinemic glucose intolerant animal [152] as it resemble the clinical and pathological features of human non-insulin-dependent diabetes mellitus (NIDDM). KK/Ay mouse model with defects in the yellow obese gene represents a condition of severe hyperinsulinaemia, hyperglycaemia, glucose intolerance and obesity due to defective insulin receptor and post-receptor signaling [153]. There are other models of the spontaneously developed IR strains [154]. Although the above-mentioned animal models provided a lot of information about the mechanisms of IR, they did not answer all the questions related to the development of IR in human tissues and relationship between IR and $\beta$-cell dysfunction.

\section{USING INDUCED PLURIPOTENT STEM CELLS (IPSCS) TO STUDY INSULIN RESISTANCE}

Although animal models provided knowledge on the pathogenesis of certain forms of IR and diabetes, they cannot reflect all pathophysiological features of human diseases due to the physiological differences between humans and animals. It has been reported that the genetic makeup of mouse model is involved in the alterations of the phenotypical outcome, even when the same mutation is created in mice with different genetic makeup. Several population-based studies have been reported, in which the biopsies are isolated from both IR and insulin sensitive individuals to determine the mechanisms underlying IR $[155,156]$. The primary endothelial cell based methodologies have been used to study the vascular inflammation in diabetes and atherosclerosis [157]. However, it also has certain limitations such as lack of donor availability and limited lifespan of primary cells. Also, it is difficult to access human tissues, such as hepatocytes, and skeletal muscles, particularly at the preclinical stages of the disease. Furthermore, it is difficult to distinguish between genetic and environmental factors. Therefore, establishing a human cell model offers a great opportunity to understand the pathophysiology of human diseases. iPSCs can be generated from patients with genetic IR and diabetes (Fig. 3). Those patient specific-iPSCs can generate all insulin target cells, such as skeletal myotubes, adipocytes, and hepatocytes as well as other cell types. The generated cell types carry the same genetic signature of the patients allowing further studies to identify the genetic defects involved in the disease progression. Recent studies showed generation of iPSCs from patient with IR. In the published literatures, there are not many reports used iPSC approach to study IR and most of those studies focused on a very specific form of IR, which is due to specific mutations [38,158-160]. Two of those studies generated iPSCs from patients with INSR mutations (INSR-Mut) (Donohue syndrome) focused on the effect of INSR-Mut on pluripotency and mitochondrial function in undifferentiated INSR-Mut hiPSCs $[158,159]$. It has been shown that INSR-Mut iPSCs are defective in their self-renewal ability, because insulin and its downstream signaling are involved in regulating the unique properties of selfrenewal and pluripotency in the undifferentiated iPSCs [161,162]. The PI3K, one of the insulin downstream signaling, has been shown to be crucial for self-renewal of pluripotent stem cells [162]. Also, the INSR-Mut-iPSCs have mitochondrial dysfunctions, including alterations in the number and the size of mitochondria and were associated with an upregulation in the expression of mitochondrial fission factor (MFF) and inverted formin 2 (INF2) [159]. These two genes are known to enhance the mitochondrial fission indicating the increase of the mitochondrial fission in IR-Mut-hiPSCs [159]. Interestingly, increased mitochondrial fission has previously been detected in adult tissues, such as pancreatic $\beta$-cells and skeletal muscle of T2D patients [33,163]. Furthermore, it has been reported that mitochondrial DNA variation could be associated with genetic alteration in known risk factors for T2D [164]. Also, the expression of glycolytic enzymes is downregulated while lactate production is increased. These events lead to enhancement of ADP/ATP ratio and 5' AMP-activated protein kinase (AMPK) activity as well as leading to inefficient ATP and decrease in energy production with increase 
in the oxidative stress [165]. All the derived INSR-Mut hiPSCs showed reduced proliferation and defected INSR phosphorylation and defects in its downstream signaling pathway such as, AKT, GSK3, ERK1 and ERK2 [158]. Differentiation of INSR-Mut hiPSCs towards skeletal myotubes exhibits defect in insulin signaling, glucose uptake, glycogen accumulation and altered insulin signaling gene expression [166], indicating the genetic defects in the skeletal myotubes. Another iPSC model for IR, in which iPSCs have been generated from the fibroblast of insulin resistant patient with congenital generalized lipodystrophy (CGL), an autosomal recessive disease due to BSCL2 mutation [90]. These patient-specific iPSCs have been used as an in vitro model to study the physiopathology of lipid accumulation and lipodystrophy and its relation to IR. Adipocytes derived from these BSCL2-Mut iPSCs showed reduced lipid droplet formation and dispersed cytoplasmic distribution of adipose differentiation related protein (ADRP) [167]. Recent studies showed the ability to generate adipocytes from hiPSCs. It has been reported that hiPSC-derived adipocytes, transplanted into mice, are able to sustain their functional characteristics for several weeks $[168,169]$, suggesting that these cells can be also used therapeutically to improve metabolic disorder conditions in patients. Therefore, differentiation of patient-specific hiPSCs into white adipocytes can offer a large number of functional adipocytes for transplantation as a possible way to treat adipocytes-associated disorders as well as studying IR. Since the liver is an important insulin target tissue, the iPSCs were used to interpret the etiology of steatosis due to the NAFLD, which is accompanied by IR and hyperlipidemia. The iPSCs generated from patients with liver steatosis showed a decrease in the AKT/mTOR signaling molecule and the phenotypes of IR are observed in both liver and skin fibroblasts of the patients. Additionally, it showed that the transcription factor, sterol regulatory element binding transcription factor 1 (SREBF1) and its downstream targets like LIPIN1 (LPIN) and low density lipoprotein receptor are involved in glycerolipid and fatty acid biosynthesis [170]. Recently, we generated the first iPSCs from patients with psoriasis and insulin resistance. Our study showed that iPSC-derived keratinocytes carry genetic defects associated with insulin resistance [171], indicating that the IR in patients with psoriasis is due to genetic defects in signaling pathways regulating insulin sensitivity in the epidermal keratinocytes. Further studies are required to fill the gaps in understanding the pathogenesis of IR and diabetes. There are several genetic factors involved in the development of IR; therefore, patient-specific iPSCs can be used to study the most common form of IR leading to T2D. Also, hiPSCs/hESCs can be genetically edited using genome editing tools, such as Crisper/CAS9. The combination of these technologies may provide more details about the inherited factors underlying the development of different forms of IR.

\section{LIMITATIONS OF IPSCS AS AN IN VITRO MODEL}

There are some challenges of using iPSC-based models. For example, robust protocols are needed for the differentiation of iPSCs into the desired cell types for studying metabolic diseases. Although there are certain protocols available for the efficient differentiation of iPSCs into a specified cell type, but most of them lead to a combination of diverse cell types. The variability in the biological properties of iPSCs derived from different individuals shows the difference in the differentiation nature towards a given lineage. This reasonably affects the consistency of interpretation of the phenotypes $[172,173]$. The results obtained from populations of different genetic background may show differences. For instance, a report emphasized that population based gene sequencing shows significant variations in human genome [174]. Hence, generating iPSCs from patients with genetic factors, differentiating them to specified cell types may hold a noteworthy risk [175]. Generation of iPSC model for IR is comparatively tough process because the development of metabolic diseases is typically slow and it shows weak phenotypic changes under in vitro conditions [175]. Genome editing in iPSCs can be used to study candidate genes involved in IR and diabetes [176]. Also, generation of isogenic cell line from iPSCs could be a worthy strategy to overcome the problem of differences in the genetic background. The isogenic cell line possesses similar genetic milieu, epigenetic nature and differentiation properties. This strategy may provide more consistent output and interpretation for complex diseases. The genome editing tools can make this strategy possible by engineering the genomic of iPSCs. There are several 
reports highlighting the use of genome editing tool for generation of iPSC-based disease models $[175,177]$.

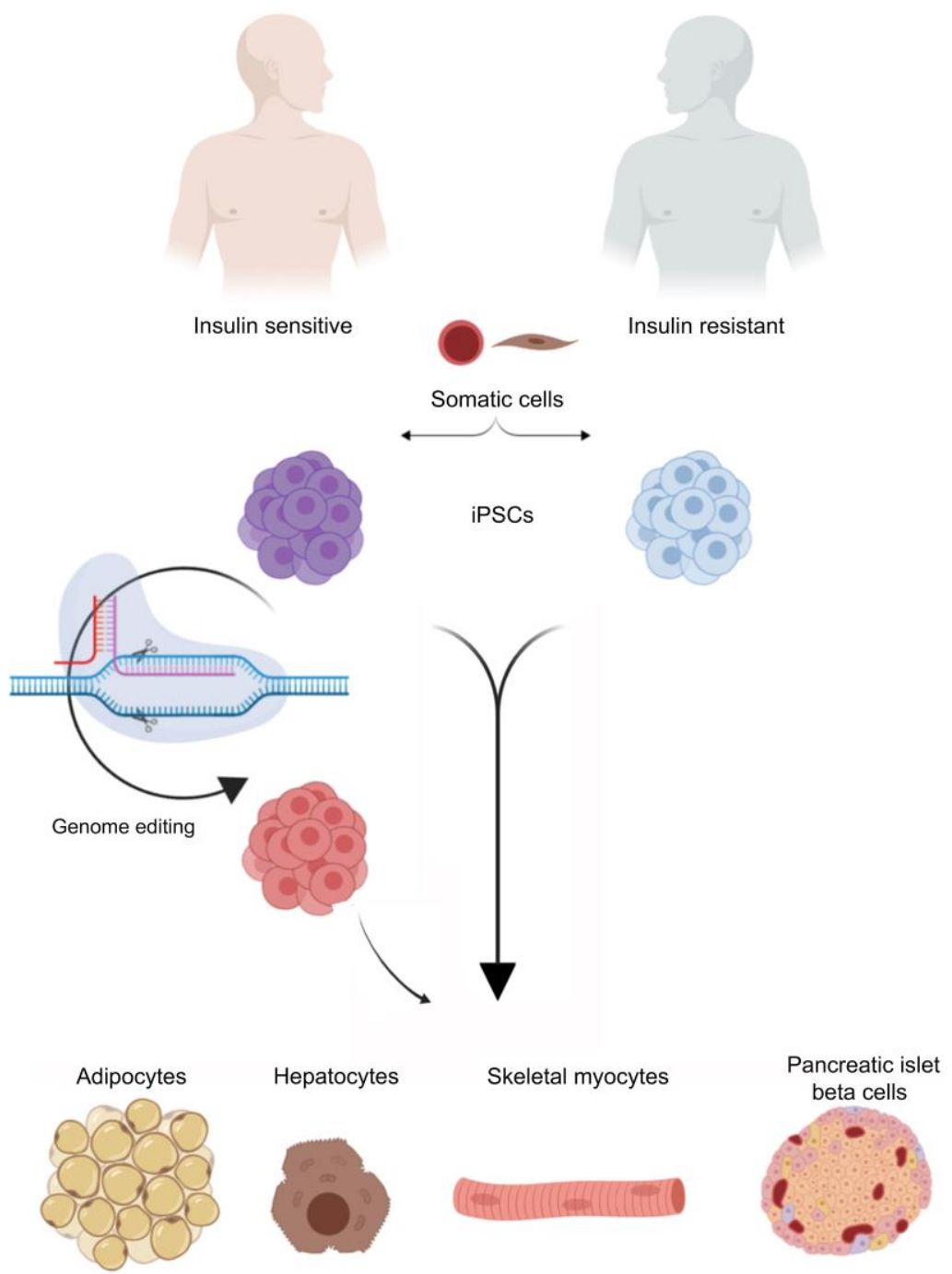

Figure 3. Using hiPSCs to study insulin resistance (IR). A schematic diagram showing the possibility of using iPSCs to study IR with special focus on the genetic factors. Somatic cells are reprogrammed into pluripotency to generate iPSCs carrying the genetic signatures of insulin sensitive (IS) and IR individuals. The generated iPSCs can be differentiated in vitro into the main insulin-target cells, including hepatocyte, adipocyte, and skeletal myotubes as well as insulin producing $\beta$-cells. Genome editing tools can be used to correct specific mutations in the generated iPSCs to establish the isogenic iPSC control. Studying those cells can help in understanding the signaling pathways involved in the development of IR and T2D. Also, these iPSC-based models can be used for drug screening.

\section{CONCLUSIONS AND FUTURE PERSPECTIVES}

The metabolic diseases like diabetes leads to several life-threatening complications. To develop a regenerative medicine for metabolic diseases, it is important to understand the factors involved in the development of the disease. The iPSC technology provides a great opportunity to supply different kind of cells from healthy and diseased individuals. Furthermore, iPSCs generated from IR patients enable to conquer a successful disease model and it helps to understand the disease nature and drug discovery. Studies on human genetics shows that numerous genes or genomic loci related to different metabolic diseases are present. The functions of these genes largely remain unknown. The current progress in genome editing tool permits fast and efficient edit of any interested gene or genomic locus in iPSCs. Gene editing tool-based generation of a robust method for iPSC differentiation into given metabolic 
disease specific cells are brought forward to avail a successful point to characterize specific gene. However, combining genome editing tool and iPSCs have certain limitations. Most of the metabolic diseases are not caused by a single gene dysfunction, but a group of complex genes are involved in regulation of metabolic diseases. Development of iPSC differentiation protocols is very important to generate a homogenous population of the target cell. One of the limitations of the genome editing tools is the off-target effect. Therefore, improving the gene-editing process is critical to avoid the off-target effects.

\section{Competing interests}

The authors declare that they have no conflict of interest.

\section{Ethical approval}

This article does not contain any studies with human or animal subjects performed by any of the authors.

\section{Funding}

This work was funded by grants from Qatar National Research Fund (QNRF) (Grant No. NPRP9-2833-056 \& NPRP10-1221-160041).

\section{REFERENCES}

1. Martin, B.C.; Warram, J.H.; Rosner, B.; Rich, S.S.; Soeldner, J.S.; Krolewski, A.S. Familial clustering of insulin sensitivity. Diabetes 1992, 41, 850-854.

2. Shulman, R.G. Nuclear magnetic resonance studies of glucose metabolism in noninsulin-dependent diabetes mellitus subjects. Mol Med 1996, 2, 533-540.

3. Ling, C.; Rönn, T. Epigenetics in human obesity and type 2 diabetes. Cell metabolism 2019.

4. $\quad$ Ling, C.; Rönn, T. Epigenetic markers to further understand insulin resistance. Diabetologia 2016, 59, 2295-2297.

5. $\quad$ Elgzyri, T.; Parikh, H.; Zhou, Y.; Dekker Nitert, M.; Ronn, T.; Segerstrom, A.B.; Ling, C.; Franks, P.W.; Wollmer, P.; Eriksson, K.F., et al. First-degree relatives of type 2 diabetic patients have reduced expression of genes involved in fatty acid metabolism in skeletal muscle. J Clin Endocrinol Metab 2012, 97, E1332-1337, doi:10.1210/jc.2011-3037.

6. Patti, M.E.; Butte, A.J.; Crunkhorn, S.; Cusi, K.; Berria, R.; Kashyap, S.; Miyazaki, Y.; Kohane, I.; Costello, M.; Saccone, R., et al. Coordinated reduction of genes of oxidative metabolism in humans with insulin resistance and diabetes: Potential role of PGC1 and NRF1. Proc Natl Acad Sci U S A 2003, 100, 8466-8471, doi:10.1073/pnas.1032913100.

7. Mootha, V.K.; Lindgren, C.M.; Eriksson, K.F.; Subramanian, A.; Sihag, S.; Lehar, J.; Puigserver, P.; Carlsson, E.; Ridderstrale, M.; Laurila, E., et al. PGC-1alpharesponsive genes involved in oxidative phosphorylation are coordinately downregulated in human diabetes. Nat Genet 2003, 34, 267-273, doi:10.1038/ng1180.

8. Al-Khawaga, S.; Memon, B.; Butler, A.E.; Taheri, S.; Abou-Samra, A.B.; Abdelalim, E.M. Pathways governing development of stem cell-derived pancreatic beta cells: lessons from embryogenesis. Biol Rev Camb Philos Soc 2018, 93, 364-389, doi:10.1111/brv.12349.

9. Bratanova-Tochkova, T.K.; Haiying, C.; Samira, D.; Subhadra, G.; Jia, L.Y.; Jennifer, M.-M.; Thomas, S.; G., S.S.; Hiroki, Y.; G., S.G.W. Triggering and augmentation 
mechanisms, granule pools, and biphasic insulin secretion. 2002, 10.2337/diabetes.51.2007.s83, doi:10.2337/diabetes.51.2007.s83.

10. Dodson, G.; Don, S. The role of assembly in insulin's biosynthesis. Current Opinion in Structural Biology 1998, 10.1016/s0959-440x(98)80037-7, doi:10.1016/s0959440x(98)80037-7.

11. Burks, D.J.; F., W.M. IRS proteins and beta-cell function. Diabetes 2001, 10.2337/diabetes.50.2007.s140, doi:10.2337/diabetes.50.2007.s140.

12. Saltiel, A.R.; Kahn, C.R. Insulin signalling and the regulation of glucose and lipid metabolism. 2001; 10.1038/414799a.

13. Smith, U. Impaired ('diabetic') insulin signaling and action occur in fat cells long before glucose intolerance - Is insulin resistance initiated in the adipose tissue? 2002; 10.1038/sj.ijo.0802028.

14. Khan, A.; Pessin, J. Insulin regulation of glucose uptake: a complex interplay of intracellular signalling pathways. Diabetologia 2002, 45, 1475-1483.

15. Hunter, S.J.; Garvey, W.T. Insulin action and insulin resistance: Diseases involving defects in insulin receptors, signal transduction, and the glucose transport effector system. 1998; 10.1016/s0002-9343(98)00300-3.

16. Wilcox, G. Insulin and Insulin Resistance Gisela. 2005, 26, 19--39.

17. Hotamisligil, G.S. Inflammatory pathways and insulin action. International Journal of Obesity 2003, 10.1038/sj.ijo.0802502, doi:10.1038/sj.ijo.0802502.

18. Artunc, F.; Erwin, S.; Cora, W.; Andreas, F.; Norbert, S.; Ulrich, H.H. The impact of insulin resistance on the kidney and vasculature. 2016; 10.1038/nrneph.2016.145.

19. Gauthier, M.S.; B., R.N. Adipose tissue inflammation and insulin resistance: All obese humans are not created equal. 2010; 10.1042/bj20101062.

20. Krauss, R.M.; W., S.P. Metabolic abnormalities: Triglyceride and low-density lipoprotein. 2004; 10.1016/j.ecl.2004.03.016.

21. Devaraj, S.; Rosenson, R.S.; Jialal, I. Metabolic syndrome: An appraisal of the proinflammatory and procoagulant status. 2004; 10.1016/j.ecl.2004.03.008.

22. Krauss, R.M.; Siri, P.W. Metabolic abnormalities: Triglyceride and low-density lipoprotein. 2004; 10.1016/j.ecl.2004.03.016.

23. Reaven, G. The metabolic syndrome or the insulin resistance syndrome? Different names, different concepts, and different goals. 2004; 10.1016/j.ecl.2004.03.002.

24. Morrison, S.A.; Goss, A.M.; Azziz, R.; Raju, D.A.; Gower, B.A. Peri-muscular adipose tissue may play a unique role in determining insulin sensitivity/resistance in women with polycystic ovary syndrome. Human Reproduction 2017, 10.1093/humrep/dew279, doi:10.1093/humrep/dew279.

25. Peppa, M.; Chrysi, K.; Panagiotis, N.; A., R.S. Skeletal muscle insulin resistance in endocrine disease. 2010; 10.1155/2010/527850.

26. M. de la Monte, S. Brain Insulin Resistance and Deficiency as Therapeutic Targets in Alzheimers Disease. Current Alzheimer Research 2012, 10.2174/156720512799015037, doi:10.2174/156720512799015037.

27. Heni, M.; Kullmann, S.; Preissl, H.; Fritsche, A.; Häring, H.U. Impaired insulin action in the human brain: Causes and metabolic consequences. 2015; 10.1038/nrendo.2015.173.

28. Burcelin, R. Gut microbiota and immune crosstalk in metabolic disease. 2016; 10.1016/j.molmet.2016.05.016.

29. Lillioja, S.; Mott, D.M.; Howard, B.V.; Bennett, P.H.; Yki-Jarvinen, H.; Freymond, D.; Nyomba, B.L.; Zurlo, F.; Swinburn, B.; Bogardus, C. Impaired glucose tolerance as a disorder of insulin action. Longitudinal and cross-sectional studies in Pima Indians. N Engl J Med 1988, 318, 1217-1225, doi:10.1056/NEJM198805123181901. 
30. Warram, J.H.; Martin, B.C.; Krolewski, A.S.; Soeldner, J.S.; Kahn, C.R. Slow glucose removal rate and hyperinsulinemia precede the development of type II diabetes in the offspring of diabetic parents. Ann Intern Med 1990, 113, 909-915.

31. Thiebaud, D.; Jacot, E.; DeFronzo, R.A.; Maeder, E.; Jequier, E.; Felber, J.P. The effect of graded doses of insulin on total glucose uptake, glucose oxidation, and glucose storage in man. Diabetes 1982, 31, 957-963.

32. Petersen, K.F.; Dufour, S.; Befroy, D.; Garcia, R.; Shulman, G.I. Impaired mitochondrial activity in the insulin-resistant offspring of patients with type 2 diabetes. $N$ Engl J Med 2004, 350, 664-671, doi:10.1056/NEJMoa031314.

33. Kelley, D.E.; He, J.; Menshikova, E.V.; Ritov, V.B. Dysfunction of mitochondria in human skeletal muscle in type 2 diabetes. Diabetes 2002, 51, 2944-2950.

34. Krook, A.; Bjornholm, M.; Galuska, D.; Jiang, X.J.; Fahlman, R.; Myers, M.G., Jr.; Wallberg-Henriksson, H.; Zierath, J.R. Characterization of signal transduction and glucose transport in skeletal muscle from type 2 diabetic patients. Diabetes 2000, 49 , 284-292.

35. Morino, K.; Petersen, K.F.; Dufour, S.; Befroy, D.; Frattini, J.; Shatzkes, N.; Neschen, S.; White, M.F.; Bilz, S.; Sono, S., et al. Reduced mitochondrial density and increased IRS-1 serine phosphorylation in muscle of insulin-resistant offspring of type 2 diabetic parents. J Clin Invest 2005, 115, 3587-3593, doi:10.1172/JCI25151.

36. Beck-Nielsen, H. Mechanisms of insulin resistance in non-oxidative glucose metabolism: the role of glycogen synthase. J Basic Clin Physiol Pharmacol 1998, 9, 255-279.

37. Damsbo, P.; Vaag, A.; Hother-Nielsen, O.; Beck-Nielsen, H. Reduced glycogen synthase activity in skeletal muscle from obese patients with and without type 2 (noninsulin-dependent) diabetes mellitus. Diabetologia 1991, 34, 239-245.

38. Iovino, S.; Burkart, A.M.; Warren, L.; Patti, M.E.; Kahn, C.R. Myotubes derived from human-induced pluripotent stem cells mirror in vivo insulin resistance. Proc Natl Acad Sci U S A 2016, 113, 1889-1894, doi:10.1073/pnas.1525665113.

39. Adams-Huet, B.; Devaraj, S.; Siegel, D.; Jialal, I. Increased adipose tissue insulin resistance in metabolic syndrome: relationship to circulating adipokines. Metab Syndr Relat Disord 2014, 12, 503-507, doi:10.1089/met.2014.0092.

40. Saltiel, A.R.; Kahn, C.R. Insulin signalling and the regulation of glucose and lipid metabolism. Nature 2001, 414, 799-806, doi:10.1038/414799a.

41. Gustafson, B.; Hedjazifar, S.; Gogg, S.; Hammarstedt, A.; Smith, U. Insulin resistance and impaired adipogenesis. Trends Endocrinol Metab 2015, 26, 193-200, doi:10.1016/j.tem.2015.01.006.

42. Tamori, Y.; Masugi, J.; Nishino, N.; Kasuga, M. Role of peroxisome proliferatoractivated receptor-gamma in maintenance of the characteristics of mature 3T3-L1 adipocytes. Diabetes 2002, 51, 2045-2055.

43. White, M.F. IRS proteins and the common path to diabetes. Am J Physiol Endocrinol Metab 2002, 283, E413-422, doi:10.1152/ajpendo.00514.2001.

44. Almind, K.; Inoue, G.; Pedersen, O.; Kahn, C.R. A common amino acid polymorphism in insulin receptor substrate-1 causes impaired insulin signaling. Evidence from transfection studies. J Clin Invest 1996, 97, 2569-2575, doi:10.1172/JCI118705.

45. Esposito, D.L.; Li, Y.; Vanni, C.; Mammarella, S.; Veschi, S.; Della Loggia, F.; Mariani-Costantini, R.; Battista, P.; Quon, M.J.; Cama, A. A novel T608R missense mutation in insulin receptor substrate- 1 identified in a subject with type 2 diabetes impairs metabolic insulin signaling. J Clin Endocrinol Metab 2003, 88, 1468-1475, doi:10.1210/jc.2002-020933. 
46. Yoshimura, R.; Araki, E.; Ura, S.; Todaka, M.; Tsuruzoe, K.; Furukawa, N.; Motoshima, H.; Yoshizato, K.; Kaneko, K.; Matsuda, K., et al. Impact of natural IRS1 mutations on insulin signals: mutations of IRS- 1 in the PTB domain and near SH2 protein binding sites result in impaired function at different steps of IRS-1 signaling. Diabetes 1997, 46, 929-936.

47. Rondinone, C.M.; Wang, L.M.; Lonnroth, P.; Wesslau, C.; Pierce, J.H.; Smith, U. Insulin receptor substrate (IRS) 1 is reduced and IRS-2 is the main docking protein for phosphatidylinositol 3-kinase in adipocytes from subjects with non-insulindependent diabetes mellitus. Proc Natl Acad Sci U S A 1997, 94, 4171-4175.

48. Carvalho, E.; Jansson, P.A.; Axelsen, M.; Eriksson, J.W.; Huang, X.; Groop, L.; Rondinone, C.; Sjostrom, L.; Smith, U. Low cellular IRS 1 gene and protein expression predict insulin resistance and NIDDM. FASEB J 1999, 13, 2173-2178.

49. Kissebah, A.H.; Sonnenberg, G.E.; Myklebust, J.; Goldstein, M.; Broman, K.; James, R.G.; Marks, J.A.; Krakower, G.R.; Jacob, H.J.; Weber, J., et al. Quantitative trait loci on chromosomes 3 and 17 influence phenotypes of the metabolic syndrome. Proc Natl Acad Sci U S A 2000, 97, 14478-14483, doi:10.1073/pnas.97.26.14478.

50. Mori, Y.; Otabe, S.; Dina, C.; Yasuda, K.; Populaire, C.; Lecoeur, C.; Vatin, V.; Durand, E.; Hara, K.; Okada, T., et al. Genome-wide search for type 2 diabetes in Japanese affected sib-pairs confirms susceptibility genes on $3 q, 15 q$, and $20 q$ and identifies two new candidate Loci on 7p and 11p. Diabetes 2002, 51, 1247-1255.

51. Vasseur, F.; Helbecque, N.; Dina, C.; Lobbens, S.; Delannoy, V.; Gaget, S.; Boutin, P.; Vaxillaire, M.; Lepretre, F.; Dupont, S., et al. Single-nucleotide polymorphism haplotypes in the both proximal promoter and exon 3 of the APM1 gene modulate adipocyte-secreted adiponectin hormone levels and contribute to the genetic risk for type 2 diabetes in French Caucasians. Hum Mol Genet 2002, 11, 2607-2614.

52. Michael, M.D.; Kulkarni, R.N.; Postic, C.; Previs, S.F.; Shulman, G.I.; Magnuson, M.A.; Kahn, C.R. Loss of insulin signaling in hepatocytes leads to severe insulin resistance and progressive hepatic dysfunction. Mol Cell 2000, 6, 87-97.

53. Thirone, A.C.; Huang, C.; Klip, A. Tissue-specific roles of IRS proteins in insulin signaling and glucose transport. Trends Endocrinol Metab 2006, 17, 72-78, doi:10.1016/j.tem.2006.01.005.

54. Kubota, N.; Kubota, T.; Itoh, S.; Kumagai, H.; Kozono, H.; Takamoto, I.; Mineyama, T.; Ogata, H.; Tokuyama, K.; Ohsugi, M., et al. Dynamic functional relay between insulin receptor substrate 1 and 2 in hepatic insulin signaling during fasting and feeding. Cell Metab 2008, 8, 49-64, doi:10.1016/j.cmet.2008.05.007.

55. Hirashima, Y.; Tsuruzoe, K.; Kodama, S.; Igata, M.; Toyonaga, T.; Ueki, K.; Kahn, C.R.; Araki, E. Insulin down-regulates insulin receptor substrate-2 expression through the phosphatidylinositol 3-kinase/Akt pathway. J Endocrinol 2003, 179, 253-266.

56. Farese, R.V., Jr.; Zechner, R.; Newgard, C.B.; Walther, T.C. The problem of establishing relationships between hepatic steatosis and hepatic insulin resistance. Cell Metab 2012, 15, 570-573, doi:10.1016/j.cmet.2012.03.004.

57. Stefan, N.; Häring, H.U. The role of hepatokines in metabolism. 2013; 10.1038/nrendo.2012.258.

58. Pal, D.; Dasgupta, S.; Kundu, R.; Maitra, S.; Das, G.; Mukhopadhyay, S.; Ray, S.; Majumdar, S.S.; Bhattacharya, S. Fetuin-A acts as an endogenous ligand of TLR4 to promote lipid-induced insulin resistance. Nature Medicine 2012, 10.1038/nm.2851, doi:10.1038/nm.2851.

59. Badman, M.K.; Pissios, P.; Kennedy, A.R.; Koukos, G.; Flier, J.S.; Maratos-Flier, E. Hepatic Fibroblast Growth Factor 21 Is Regulated by PPAR $\alpha$ and Is a Key Mediator 
of Hepatic Lipid Metabolism in Ketotic States. Cell Metabolism 2007, 10.1016/j.cmet.2007.05.002, doi:10.1016/j.cmet.2007.05.002.

60. Misu, H.; Takamura, T.; Takayama, H.; Hayashi, H.; Matsuzawa-Nagata, N.; Kurita, S.; Ishikura, K.; Ando, H.; Takeshita, Y.; Ota, T., et al. A liver-derived secretory protein, selenoprotein P, causes insulin resistance. Cell Metabolism 2010, 10.1016/j.cmet.2010.09.015, doi:10.1016/j.cmet.2010.09.015.

61. Hashiramoto, M.; Osawa, H.; Ando, M.; Murakami, A.; Nishimiya, T.; Nakano, M.; Nishida, W.; Onuma, H.; Makino, H. A nonsense mutation in the Arg345 of the insulin receptor gene in a Japanese type A insulin-resistant patient. Endocr $J \mathbf{2 0 0 5}$, 52, 499-504.

62. Kosztolnyi, G. Leprechaunism/Donohue syndrome/insulin receptor gene mutations: A syndrome delineation story from clinicopathological description to molecular understanding. European Journal of Pediatrics 1997, 10.1007/s004310050594, doi:10.1007/s004310050594.

63. Longo, N.; Yuhuan, W.; Marzia, P. Progressive decline in insulin levels in RabsonMendenhall syndrome. Journal of Clinical Endocrinology and Metabolism 1999, 10.1210/jc.84.8.2623, doi:10.1210/jc.84.8.2623.

64. Musso, C.; Elaine, C.; Ann, M.S.; and, S.M.C. Clinical course of genetic diseases of the insulin receptor (type A and Rabson-Mendenhall syndromes): A 30-year prospective. Medicine 2004, 10.1097/01.md.0000133625.73570.54, doi:10.1097/01.md.0000133625.73570.54.

65. Taylor, S.I.; T., K.; H., K.; D., A.; A., C.; C., M. Mutations in insulin-receptor gene in insulin-resistant patients. 1990, 10.2337/diacare.13.3.257, doi:10.2337/diacare.13.3.257.

66. Accili, D.; Drago, J.; Lee, E.J.; Johnson, M.D.; Cool, M.H.; Salvatore, P.; Asico, L.D.; José, P.A.; Taylor, S.I.; Westphal, H. Early neonatal death in mice homozygous for a null allele of the insulin receptor gene. Nature genetics 1996, 12, 106.

67. Joshi, R.L.; Lamothe, B.; Cordonnier, N.; Mesbah, K.; Monthioux, E.; Jami, J.; Bucchini, D. Targeted disruption of the insulin receptor gene in the mouse results in neonatal lethality. The EMBO journal 1996, 15, 1542-1547.

68. Kadowaki, T.; Bevins, C.L.; Cama, A.; Ojamaa, K.; Marcus-Samuels, B.; Kadowaki, H.; Beitz, L.; McKeon, C.; Taylor, S.I. Two mutant alleles of the insulin receptor gene in a patient with extreme insulin resistance. Science 1988, 240, 787-790.

69. Yoshimasa, Y.; Seino, S.; Whittaker, J.; Kakehi, T.; Kosaki, A.; Kuzuya, H.; Imura, H.; Bell, G.I.; Steiner, D.F. Insulin-resistant diabetes due to a point mutation that prevents insulin proreceptor processing. Science 1988, 240, 784-787.

70. Odawara, M.; Kadowaki, T.; Yamamoto, R.; Shibasaki, Y.; Tobe, K.; Accili, D.; Bevins, C.; Mikami, Y.; Matsuura, N.; Akanuma, Y. Human diabetes associated with a mutation in the tyrosine kinase domain of the insulin receptor. Science 1989, 245, 66-68.

71. Sigal, R.; Doria, A.; Warram, J.; Krolewski, A. Codon 972 polymorphism in the insulin receptor substrate-1 gene, obesity, and risk of noninsulin-dependent diabetes mellitus. The Journal of Clinical Endocrinology \& Metabolism 1996, 81, 1657-1659.

72. Chudasama, K.K.; Jonathon, W.; Stefan, J.; Tor, C.; Rainer, K.; Ingfrid, H.; Bente, J.; Rang, W.J.; Dagfinn, A.; V., S.J., et al. SHORT syndrome with partial lipodystrophy due to impaired phosphatidylinositol 3 kinase signaling. American Journal of Human Genetics 2013, 10.1016/j.ajhg.2013.05.023, doi:10.1016/j.ajhg.2013.05.023.

73. Dyment, D.A.; C., S.A.; Diana, A.; A., S.J.; Lina, B.-V.; J., C.C.; Karen, T.I.; William, R.; Sahar, M.; R., H.M., et al. Mutations in PIK3R1 cause SHORT 
syndrome. American Journal of Human Genetics 2013, 10.1016/j.ajhg.2013.06.005, doi:10.1016/j.ajhg.2013.06.005.

74. Thauvin-Robinet, C.; Auclair, M.; Duplomb, L.; Caron-Debarle, M.; Avila, M.; StOnge, J.; Le Merrer, M.; Le Luyer, B.; Héron, D.; Mathieu-Dramard, M., et al. PIK3R1 mutations cause syndromic insulin resistance with lipoatrophy. American Journal of Human Genetics 2013, 10.1016/j.ajhg.2013.05.019, doi:10.1016/j.ajhg.2013.05.019.

75. George, S.; Rochford, J.J.; Wolfrum, C.; Gray, S.L.; Schinner, S.; Wilson, J.C.; Soos, M.A.; Murgatroyd, P.R.; Williams, R.M.; Acerini, C.L., et al. A family with severe insulin resistance and diabetes due to a mutation in AKT2. Science 2004, 304, 13251328, doi:10.1126/science.1096706.

76. Dash, S.; Sano, H.; Rochford, J.J.; Semple, R.K.; Yeo, G.; Hyden, C.S.; Soos, M.A.; Clark, J.; Rodin, A.; Langenberg, C., et al. A truncation mutation in TBC1D4 in a family with acanthosis nigricans and postprandial hyperinsulinemia. Proc Natl Acad Sci U S A 2009, 106, 9350-9355, doi:10.1073/pnas.0900909106.

77. Dash, S.; Hiroyuki, S.; J., R.J.; K., S.R.; Giles, Y.; S., H.C.S.; A., S.M.; James, C.; Andrew, R.; Claudia, L., et al. A truncation mutation in TBC1D4 in a family with acanthosis nigricans and postprandial hyperinsulinemia. Proceedings of the National Academy of Sciences of the United States of America 2009, 10.1073/pnas.0900909106, doi:10.1073/pnas.0900909106.

78. JØRgensen, M.E.; Tvermosegaard, M.; RØNn, P.F.; Bjerregaard, P.; Dahl-Petersen, I.K.; Larsen, C.V.; Pedersen, M.L.; Albrechtsen, A.; Moltke, I.D.A.; Grarup, N., et al. Do Greenlandic Carriers of the TBC1D4 p.Arg684Ter Variant Have Increased Risk of Cardiovascular Disease? Diabetes 2018, 10.2337/db18-439-p, doi:10.2337/db18439-p.

79. Moltke, I.; Grarup, N.; Jørgensen, M.E.; Bjerregaard, P.; Treebak, J.T.; Fumagalli, M.; Korneliussen, T.S.; Andersen, M.A.; Nielsen, T.S.; Krarup, N.T., et al. A common Greenlandic TBC1D4 variant confers muscle insulin resistance and type 2 diabetes. Nature 2014, 10.1038/nature13425, doi:10.1038/nature13425.

80. Jrgensen, M.E.; Maria, T.; F., R.N.N.P.; Peter, B.; K., D.-P.I.; V., L.C.; L., P.M.; Anders, A.; A., M.I.D.; Niels, G., et al. Do Greenlandic Carriers of the TBC1D4 p.Arg684Ter Variant Have Increased Risk of Cardiovascular Disease? Diabetes 2018, 10.2337/db18-439-p, doi:10.2337/db18-439-p.

81. Moltke, I.; Niels, G.; E., J.M.; Peter, B.; T., T.J.; Matteo, F.; S., K.T.; A., A.M.; S., N.T.; T., K.N., et al. A common Greenlandic TBC1D4 variant confers muscle insulin resistance and type 2 diabetes. Nature 2014, 10.1038/nature13425, doi:10.1038/nature13425.

82. Minton, J.A.; Owen, K.R.; Ricketts, C.J.; Crabtree, N.; Shaikh, G.; Ehtisham, S.; Porter, J.R.; Carey, C.; Hodge, D.; Paisey, R., et al. Syndromic obesity and diabetes: changes in body composition with age and mutation analysis of ALMS1 in 12 United Kingdom kindreds with Alstrom syndrome. J Clin Endocrinol Metab 2006, 91, 31103116, doi:10.1210/jc.2005-2633.

83. Savage, D.B.; Zhai, L.; Ravikumar, B.; Choi, C.S.; Snaar, J.E.; McGuire, A.C.; Wou, S.E.; Medina-Gomez, G.; Kim, S.; Bock, C.B., et al. A prevalent variant in PPP1R3A impairs glycogen synthesis and reduces muscle glycogen content in humans and mice. PLoS Med 2008, 5, e27, doi:10.1371/journal.pmed.0050027.

84. Savage, D.B.; Agostini, M.; Barroso, I.; Gurnell, M.; Luan, J.; Meirhaeghe, A.; Harding, A.H.; Ihrke, G.; Rajanayagam, O.; Soos, M.A., et al. Digenic inheritance of severe insulin resistance in a human pedigree. Nat Genet 2002, 31, 379-384, doi:10.1038/ng926. 
85. Yamada, K.; Ikegami, H.; Yoneda, H.; Miki, T.; Ogihara, T. All patients with Werner's syndrome are insulin resistant, but only those who also have impaired insulin secretion develop overt diabetes. Diabetes Care 1999, 22, 2094-2095.

86. Payne, F.; Colnaghi, R.; Rocha, N.; Seth, A.; Harris, J.; Carpenter, G.; Bottomley, W.E.; Wheeler, E.; Wong, S.; Saudek, V., et al. Hypomorphism in human NSMCE2 linked to primordial dwarfism and insulin resistance. J Clin Invest 2014, 124, 40284038, doi:10.1172/JCI73264.

87. Weedon, M.N.; Ellard, S.; Prindle, M.J.; Caswell, R.; Lango Allen, H.; Oram, R.; Godbole, K.; Yajnik, C.S.; Sbraccia, P.; Novelli, G., et al. An in-frame deletion at the polymerase active site of POLD1 causes a multisystem disorder with lipodystrophy. Nat Genet 2013, 45, 947-950, doi:10.1038/ng.2670.

88. Semple, R.K. How does insulin resistance arise, and how does it cause disease? Human genetic lessons. 2016; 10.1530/eje-15-1131.

89. Agarwal, A.K.; Elif, A.; Salome, d.A.; Nurullah, A.; I., T.S.; M., B.A.; I., B.R.; Abhimanyu, G. AGPAT2 is mutated in congenital generalized lipodystrophy linked to chromosome 9q34. Nature Genetics 2002, 10.1038/ng880, doi:10.1038/ng880.

90. Garg, A. Acquired and Inherited Lipodystrophies. 2004; 10.1056/NEJMra025261.

91. Magré, J.; Delépine, M.; Khallouf, E.; Gedde-Dahl, T.; Van Maldergem, L.; Sobel, E.; Papp, J.; Meier, M.; Mégarbané, A.; Bachy, A., et al. Identification of the gene altered in Berardinelli-Seip congenital lipodystrophy on chromosome 11q13. Nature Genetics 2001, 10.1038/ng585, doi:10.1038/ng585.

92. Hayashi, Y.K.; Chie, M.; Megumu, O.; Kanako, G.; Kayo, T.; Satomi, M.; Eun, P.Y.; Ikuya, N.; Naomi, H.-F.; Kazuhiro, H., et al. Human PTRF mutations cause secondary deficiency of caveolins resulting in muscular dystrophy with generalized lipodystrophy. Journal of Clinical Investigation 2009, 10.1172/jci38660, doi:10.1172/jci38660.

93. Kim, C.A.; Marc, D.; and, B.E. Association of a homozygous nonsense caveolin-1 mutation with berardinelli-seip congenital lipodystrophy. Journal of Clinical Endocrinology and Metabolism 2008, 10.1210/jc.2007-1328, doi:10.1210/jc.20071328.

94. Payne, F.; Koini, L.; Amandine, G.; J., B.R.; Nora, K.; Ann, R.; Yali, X.; Alison, S.; Elaine, C.; Claire, A., et al. Mutations disrupting the Kennedy phosphatidylcholine pathway in humans with congenital lipodystrophy and fatty liver disease. Proceedings of the National Academy of Sciences of the United States of America 2014, 10.1073/pnas.1408523111, doi:10.1073/pnas.1408523111.

95. Shackleton, S.; J., L.D.; J., J.S.N.; Richard, E.; F., N.M.; M., S.B.; Hartmut, S.; Georg, B.; Sudesh, K.; N., D.P., et al. LMNA, encoding lamin A/C, is mutated in partial lipodystrophy. Nature Genetics 2000, 10.1038/72807, doi:10.1038/72807.

96. Semple, R.K.; Chatterjee, V.K.K.; O'Rahilly, S. PPAR gamma and human metabolic disease. Journal of Clinical Investigation 2006.

97. Ali, A.T.; Hochfeld, W.E.; Myburgh, R.; Pepper, M.S. Adipocyte and adipogenesis. European journal of cell biology 2013, 92, 229-236.

98. Gandotra, S.a. Perilipin deficiency and autosomal dominant partial lipodystrophy. New England Journal of Medicine 2011, 10.1056/NEJMoa1007487, doi:10.1056/NEJMoa1007487.

99. Kozusko, K.; Satish, P.; B., S.D. Human congenital perilipin deficiency and insulin resistance. 2013, 10.1159/000342511, doi:10.1159/000342511.

100. Thauvin-Robinet, C.; Martine, A.; Laurence, D.; Martine, C.-D.; Magali, A.; and, S.O.J. PIK3R1 mutations cause syndromic insulin resistance with lipoatrophy. 
American Journal of Human Genetics 2013, 10.1016/j.ajhg.2013.05.019, doi:10.1016/j.ajhg.2013.05.019.

101. George, S.; J., R.J.; Christian, W.; L., G.S.; Sven, S.; C., W.J.; A., S.M.; R., M.P.; M., W.R.; L., A.C., et al. A family with severe insulin resistance and diabetes due to a mutation in AKT2. Science 2004, 10.1126/science.1096706, doi:10.1126/science.1096706.

102. Ashcroft, F.M.; Rorsman, P. Diabetes mellitus and the $\beta$ cell: The last ten years. 2012; 10.1016/j.cell.2012.02.010.

103. Ferrannini, E. The Stunned $\beta$ Cell: A Brief History. Cell metabolism 2010.

104. Talchai, C.; Xuan, S.; Lin, H.V.; Sussel, L.; Accili, D. Pancreatic $\beta$ cell dedifferentiation as a mechanism of diabetic $\beta$ cell failure. Cell 2012, 10.1016/j.cell.2012.07.029, doi:10.1016/j.cell.2012.07.029.

105. Prentki, M.; Nolan, C.J. Islet $\beta$ cell failure in type 2 diabetes. 2006; 10.1172/jci29103.

106. Kasuga, M. Insulin resistance and pancreatic $\beta$ cell failure. 2006; 10.1172/jci29189.

107. Hasnain, S.Z.; Borg, D.J.; Harcourt, B.E.; Tong, H.; Sheng, Y.H.; Ng, C.P.; Das, I.; Wang, R.; Chen, A.C.H.; Loudovaris, T., et al. Glycemic control in diabetes is restored by therapeutic manipulation of cytokines that regulate beta cell stress. Nature Medicine 2014, 10.1038/nm.3705, doi:10.1038/nm.3705.

108. Poitout, V.; Robertson, R.P. Glucolipotoxicity: Fuel excess and $\beta$-cell dysfunction. 2008; 10.1210/er.2007-0023.

109. Khaldi, M.Z.; Guiot, Y.; Gilon, P.; Henquin, J.C.; Jonas, J.C. Increased glucose sensitivity of both triggering and amplifying pathways of insulin secretion in rat islets cultured for $1 \mathrm{wk}$ in high glucose. American Journal of Physiology - Endocrinology and Metabolism 2004, 10.1152/ajpendo.00426.2003, doi:10.1152/ajpendo.00426.2003.

110. Patanè, G.; Anello, M.; Piro, S.; Vigneri, R.; Purrello, F.; Rabuazzo, A.M. Role of ATP production and uncoupling protein-2 in the insulin secretory defect induced by chronic exposure to high glucose or free fatty acids and effects of peroxisome proliferator-activated receptor- $\gamma$ inhibition. Diabetes 2002, 10.2337/diabetes.51.9.2749, doi:10.2337/diabetes.51.9.2749.

111. Federici, M.; Hribal, M.; Perego, L.; Ranalli, M.; Caradonna, Z.; Perego, C.; Usellini, L.; Nano, R.; Bonini, P.; Bertuzzi, F., et al. High glucose causes apoptosis in cultured human pancreatic islets of Langerhans: A potential role for regulation of specific $\mathrm{Bcl}$ family genes toward an apoptotic cell death program. Diabetes 2001, 10.2337/diabetes.50.6.1290, doi:10.2337/diabetes.50.6.1290.

112. Van Raalte, D.H.; Diamant, M. Glucolipotoxicity and beta cells in type 2 diabetes mellitus: Target for durable therapy? Diabetes Research and Clinical Practice 2011, 10.1016/s0168-8227(11)70012-2, doi:10.1016/s0168-8227(11)70012-2.

113. Cunha, D.A.; Hekerman, P.; Ladrière, L.; Bazarra-Castro, A.; Ortis, F.; Wakeham, M.C.; Moore, F.; Rasschaert, J.; Cardozo, A.K.; Bellomo, E. Initiation and execution of lipotoxic ER stress in pancreatic $\beta$-cells. Journal of cell science 2008, 121, 23082318.

114. Cnop, M.; Ladrière, L.; Igoillo-Esteve, M.; Moura, R.F.; Cunha, D. Causes and cures for endoplasmic reticulum stress in lipotoxic $\beta$-cell dysfunction. Diabetes, obesity and metabolism 2010, 12, 76-82.

115. Igoillo-Esteve, M.; Marselli, L.; Cunha, D.; Ladrière, L.; Ortis, F.; Grieco, F.A.; Dotta, F.; Weir, G.; Marchetti, P.; Eizirik, D.L. Palmitate induces a pro-inflammatory response in human pancreatic islets that mimics CCL2 expression by beta cells in type 2 diabetes. Diabetologia 2010, 53, 1395-1405. 
116. Boslem, E.; MacIntosh, G.; Preston, A.M.; Bartley, C.; Busch, A.K.; Fuller, M.; Laybutt, D.R.; Meikle, P.J.; Biden, T.J. A lipidomic screen of palmitate-treated MIN6 $\beta$-cells links sphingolipid metabolites with endoplasmic reticulum (ER) stress and impaired protein trafficking. Biochemical Journal 2011, 435, 267-276.

117. Kelpe, C.L.; Moore, P.C.; Parazzoli, S.D.; Wicksteed, B.; Rhodes, C.J.; Poitout, V. Palmitate inhibition of insulin gene expression is mediated at the transcriptional level via ceramide synthesis. Journal of Biological Chemistry 2003, 10.1074/jbc.M302548200, doi:10.1074/jbc.M302548200.

118. Solinas, G.; Naugler, W.; Galimi, F.; Lee, M.S.; Karin, M. Saturated fatty acids inhibit induction of insulin gene transcription by JNK-mediated phosphorylation of insulin-receptor substrates. Proceedings of the National Academy of Sciences of the United States of America 2006, 10.1073/pnas.0607626103, doi:10.1073/pnas.0607626103.

119. Yaney, G.; Corkey, B. Fatty acid metabolism and insulin secretion in pancreatic beta cells. Diabetologia 2003, 46, 1297-1312.

120. Gastaldelli, A. Role of beta-cell dysfunction, ectopic fat accumulation and insulin resistance in the pathogenesis of type 2 diabetes mellitus. Diabetes Research and Clinical Practice 2011, 10.1016/s0168-8227(11)70015-8, doi:10.1016/s01688227(11)70015-8.

121. Lim, E.L.; Hollingsworth, K.G.; Aribisala, B.S.; Chen, M.J.; Mathers, J.C.; Taylor, R. Reversal of type 2 diabetes: Normalisation of beta cell function in association with decreased pancreas and liver triacylglycerol. Diabetologia 2011, 10.1007/s00125011-2204-7, doi:10.1007/s00125-011-2204-7.

122. Donath, M.Y.; Dalmas, É.; Sauter, N.S.; Böni-Schnetzler, M. Inflammation in obesity and diabetes: Islet dysfunction and therapeutic opportunity. 2013; 10.1016/j.cmet.2013.05.001.

123. Choi, H.J.; Hwang, S.; Lee, S.H.; Lee, Y.R.; Shin, J.; Park, K.S.; Cho, Y.M. Genomewide identification of palmitate-regulated immediate early genes and target genes in pancreatic beta-cells reveals a central role of NF- $\mathrm{KB}$. Molecular Biology Reports 2012, 10.1007/s11033-012-1503-5, doi:10.1007/s11033-012-1503-5.

124. Cnop, M.; Welsh, N.; Jonas, J.C.; Jörns, A.; Lenzen, S.; Eizirik, D.L. Mechanisms of pancreatic $\beta$-cell death in type 1 and type 2 diabetes: Many differences, few similarities. 2005; 10.2337/diabetes.54.suppl_2.S97.

125. Eizirik, D.L.; Cnop, M. ER stress in pancreatic ?? cells: The thin red line between adaptation and failure. 2010; 10.1126/scisignal.3110pe7.

126. Gurgul-Convey, E.; Mehmeti, I.; Lortz, S.; Lenzen, S. Cytokine toxicity in insulinproducing cells is mediated by nitro-oxidative stress-induced hydroxyl radical formation in mitochondria. Journal of Molecular Medicine 2011, 10.1007/s00109011-0747-1, doi:10.1007/s00109-011-0747-1.

127. Donath, M.Y.; E., S.S. Type 2 diabetes as an inflammatory disease. 2011; 10.1038/nri2925.

128. Lin, X.; Qin, Y.; Jia, J.; Lin, T.; Lin, X.; Chen, L.; Zeng, H.; Han, Y.; Wu, L.; Huang, $\mathrm{S}$. MiR-155 enhances insulin sensitivity by coordinated regulation of multiple genes in mice. PLoS genetics 2016, 12, e1006308.

129. Robertson, R.; Huarong, Z.; Tao, Z.; S., H.J. Chronic oxidative stress as a mechanism for glucose toxicity of the beta cell in type 2 diabetes. Cell Biochemistry and Biophysics 2007, 10.1007/s12013-007-0026-5, doi:10.1007/s 12013-007-0026-5.

130. Kulkarni, R.N.; Brüning, J.C.; Winnay, J.N.; Postic, C.; Magnuson, M.A.; Ronald Kahn, C. Tissue-specific knockout of the insulin receptor in pancreatic $\beta$ cells creates 
an insulin secretory defect similar to that in type 2 diabetes. Cell 1999, 10.1016/s0092-8674(00)80546-2, doi:10.1016/s0092-8674(00)80546-2.

131. Kulkarni, R.N.; Holzenberger, M.; Shih, D.Q.; Ozcan, U.; Stoffel, M.; Magnuson, M.A.; Kahn, C.R. $\beta$-cell-specific deletion of the Igf1 receptor leads to hyperinsulinemia and glucose intolerance but does not alter $\beta$-cell mass. Nature Genetics 2002, 10.1038/ng872, doi:10.1038/ng872.

132. Xuan, S.; Kitamura, T.; Nakae, J.; Politi, K.; Kido, Y.; Fisher, P.; Morroni, M.; Cinti, S.; White, M.; Herrera, P., et al. Defective insulin secretion in pancreatic $\beta$ cells lacking type 1 IGF receptor. Journal of Clinical Investigation 2002, 10.1172/jci15276, doi:10.1172/jci15276.

133. Hashimoto, N.; Kido, Y.; Uchida, T.; Asahara, S.I.; Shigeyama, Y.; Matsuda, T.; Takeda, A.; Tsuchihashi, D.; Nishizawa, A.; Ogawa, W., et al. Ablation of PDK1 in pancreatic $\beta$ cells induces diabetes as a result of loss of $\beta$ cell mass. Nature Genetics 2006, 10.1038/ng1774, doi:10.1038/ng1774.

134. Uchida, T.; Nakamura, T.; Hashimoto, N.; Matsuda, T.; Kotani, K.; Sakaue, H.; Kido, Y.; Hayashi, Y.; Nakayama, K.I.; White, M.F., et al. Deletion of Cdkn1b ameliorates hyperglycemia by maintaining compensatory hyperinsulinemia in diabetic mice. Nature Medicine 2005, 10.1038/nm1187, doi:10.1038/nm1187.

135. Sah, S.P.; Singh, B.; Choudhary, S.; Kumar, A. Animal models of insulin resistance: A review. 2016; 10.1016/j.pharep.2016.07.010.

136. Islam, M.S.; du Loots, T. Experimental rodent models of type 2 diabetes: a review. Methods and findings in experimental and clinical pharmacology 2009, 31, 249-261.

137. Qi, J.; Yang, B.; Ren, C.; Fu, J.; Zhang, J. Swimming exercise alleviated insulin resistance by regulating tripartite motif family protein 72 expression and AKT signal pathway in Sprague-Dawley rats fed with high-fat diet. Journal of diabetes research 2016, 2016.

138. Sone, H.; Suzuki, H.; Takahashi, A.; Yamada, N. Disease model: Hyperinsulinemia and insulin resistance. Part A - Targeted disruption of insulin signaling or glucose transport. 2001; 10.1016/s1471-4914(01)02041-x.

139. Cho, H.; Mu, J.; Kim, J.K.; Thorvaldsen, J.L.; Chu, Q.; Crenshaw, E.B.; Kaestner, K.H.; Bartolomei, M.S.; Shulman, G.I.; Birnbaum, M.J. Insulin resistance and a diabetes mellitus-like syndrome in mice lacking the protein kinase Akt2 (PKB $\beta$ ). Science 2001, 10.1126/science.292.5522.1728, doi:10.1126/science.292.5522.1728.

140. Guillam, M.T.; Hümmler, E.; Schaerer, E.; Wu, J.Y.; Birnbaum, M.J.; Beermann, F.; Schmidt, A.; Dériaz, N.; Thorens, B. Early diabetes and abnormal postnatal pancreatic islet development in mice lacking Glut-2. Nature Genetics 1997, 10.1038/ng1197327, doi:10.1038/ng1197-327.

141. Duan, W.; Guo, Z.; Jiang, H.; Ware, M.; Mattson, M.P. Reversal of behavioral and metabolic abnormalities, and insulin resistance syndrome, by dietary restriction in mice deficient in brain-derived neurotrophic factor. 2003.

142. Yang, C.; Coker, K.J.; Kim, J.K.; Mora, S.; Thurmond, D.C.; Davis, A.C.; Yang, B.; Williamson, R.A.; Shulman, G.I.; Pessin, J.E. Syntaxin 4 heterozygous knockout mice develop muscle insulin resistance. Journal of Clinical Investigation 2001, 10.1172/jci12274, doi:10.1172/jci12274.

143. Shimomura, I.; Hammer, R.E.; Richardson, J.A.; Ikemoto, S.; Bashmakov, Y.; Goldstein, J.L.; Brown, M.S. Insulin resistance and diabetes mellitus in transgenic mice expressing nuclear SREBP-1c in adipose tissue: Model for congenital generalized lipodystrophy. Genes and Development 1998, 10.1101/gad.12.20.3182, doi:10.1101/gad.12.20.3182. 
144. Shimano, H.; Horton, J.D.; Shimomura, I.; Hammer, R.E.; Brown, M.S.; Goldstein, J.L. Isoform 1c of sterol regulatory element binding protein is less active than isoform 1a in livers of transgenic mice and in cultured cells. Journal of Clinical Investigation 1997, 10.1172/jci119248, doi:10.1172/jci119248.

145. Kim, J.K.; Gavrilova, O.; Chen, Y.; Reitman, M.L.; Shulman, G.I. Mechanism of insulin resistance in A-ZIP/F-1 fatless mice. Journal of Biological Chemistry 2000, 10.1074/jbc.275.12.8456, doi:10.1074/jbc.275.12.8456.

146. Shi, H.; V., K.M.; Karen, I.; Iphigenia, T.; Huali, Y.; S., F.J. TLR4 links innate immunity and fatty acid-induced insulin resistance. Journal of Clinical Investigation 2006, 10.1172/jci28898, doi:10.1172/jci28898.

147. Tartaglia, L.A.; Dembski, M.; Weng, X.; Deng, N.; Culpepper, J.; Devos, R.; Richards, G.J.; Campfield, L.A.; Clark, F.T.; Deeds, J., et al. Identification and expression cloning of a leptin receptor, OB-R. Cell 1995, 10.1016/00928674(95)90151-5, doi:10.1016/0092-8674(95)90151-5.

148. Zhang, Y.; Proenca, R.; Maffei, M.; Barone, M.; Leopold, L.; Friedman, J.M. Positional cloning of the mouse obese gene and its human homologue. Nature 1994, 10.1038/372425a0, doi:10.1038/372425a0.

149. Yekollu, S.K.; Thomas, R.; O'Sullivan, B. Targeting curcusomes to inflammatory dendritic cells inhibits NF- $\kappa \mathrm{B}$ and improves insulin resistance in obese mice. Diabetes 2011, 10.2337/db11-0275, doi:10.2337/db11-0275.

150. Oana, F.; Takeda, H.; Hayakawa, K.; Matsuzawa, A.; Akahane, S.; Isaji, M.; Akahane, M. Physiological difference between obese (fa/fa) Zucker rats and lean Zucker rats concerning adiponectin. Metabolism: Clinical and Experimental 2005, 10.1016/j.metabol.2005.02.016, doi:10.1016/j.metabol.2005.02.016.

151. King, A.J.F. The use of animal models in diabetes research. 2012; 10.1111/j.14765381.2012.01911.x.

152. Pravenec, M.; Landa, V.; Zidek, V.; Musilova, A.; Kren, V.; Kazdova, L.; Aitman, T.J.; Glazier, A.M.; Ibrahimi, A.; Abumrad, N.A., et al. Transgenic rescue of defective $\mathrm{Cd} 36$ ameliorates insulin resistance in spontaneously hypertensive rats. Nature Genetics 2001, 10.1038/84777, doi:10.1038/84777.

153. Srinivasan, K.; Ramarao, P. Animal models in type 2 diabetes research: An overview K. 2012.

154. King, A.J. The use of animal models in diabetes research. Br J Pharmacol 2012, 166, 877-894, doi:10.1111/j.1476-5381.2012.01911.x.

155. Méndez-Hernández, P.; Dosamantes-Carrasco, L.D.; Siani, C.; Pierlot, R.; MartínezGómez, M.; Rivera-Paredez, B.; Cervantes-Popoca, L.; Rojas-Lima, E.; SalazarMartínez, E.; Flores, Y.N., et al. Mealtime habits and risk of developing the metabolic syndrome or insulin resistance among Mexican adults. British Journal of Nutrition 2016, 10.1017/s0007114516003329, doi:10.1017/s0007114516003329.

156. Wu, C.; Gang, X.; A., T.S.Y.; J., F.W.; Ting, L.C. Transcriptional profiles of type 2 diabetes in human skeletal muscle reveal insulin resistance, metabolic defects, apoptosis, and molecular signatures of immune activation in response to infections. Biochemical and Biophysical Research Communications 2017, 10.1016/j.bbrc.2016.11.055, doi:10.1016/j.bbrc.2016.11.055.

157. Onat, D.; David, B.; C., C.P.; Marie, S.A. Human vascular endothelial cells: A model system for studying vascular inflammation in diabetes and atherosclerosis. 2011; 10.1007/s11892-011-0182-2.

158. Iovino, S.; Burkart, A.M.; Kriauciunas, K.; Warren, L.; Hughes, K.J.; Molla, M.; Lee, Y.K.; Patti, M.E.; Kahn, C.R. Genetic insulin resistance is a potent regulator of gene 
expression and proliferation in human iPS cells. Diabetes 2014, 63, 4130-4142, doi:10.2337/db14-0109.

159. Burkart, A.M.; Tan, K.; Warren, L.; Iovino, S.; Hughes, K.J.; Kahn, C.R.; Patti, M.E. Insulin Resistance in Human iPS Cells Reduces Mitochondrial Size and Function. Sci Rep 2016, 6, 22788, doi:10.1038/srep22788.

160. Balhara, B.; Burkart, A.; Topcu, V.; Lee, Y.K.; Cowan, C.; Kahn, C.R.; Patti, M.E. Severe insulin resistance alters metabolism in mesenchymal progenitor cells. Endocrinology 2015, 156, 2039-2048, doi:10.1210/en.2014-1403.

161. Wang, L.; Schulz, T.C.; Sherrer, E.S.; Dauphin, D.S.; Shin, S.; Nelson, A.M.; Ware, C.B.; Zhan, M.; Song, C.Z.; Chen, X., et al. Self-renewal of human embryonic stem cells requires insulin-like growth factor-1 receptor and ERBB2 receptor signaling. Blood 2007, 110, 4111-4119, doi:10.1182/blood-2007-03-082586.

162. Armstrong, L.; Hughes, O.; Yung, S.; Hyslop, L.; Stewart, R.; Wappler, I.; Peters, H.; Walter, T.; Stojkovic, P.; Evans, J., et al. The role of PI3K/AKT, MAPK/ERK and NFkappabeta signalling in the maintenance of human embryonic stem cell pluripotency and viability highlighted by transcriptional profiling and functional analysis. Hum Mol Genet 2006, 15, 1894-1913, doi:10.1093/hmg/ddl112.

163. Anello, M.; Lupi, R.; Spampinato, D.; Piro, S.; Masini, M.; Boggi, U.; Del Prato, S.; Rabuazzo, A.M.; Purrello, F.; Marchetti, P. Functional and morphological alterations of mitochondria in pancreatic beta cells from type 2 diabetic patients. Diabetologia 2005, 48, 282-289, doi:10.1007/s00125-004-1627-9.

164. Pravenec, M.; Hyakukoku, M.; Houstek, J.; Zidek, V.; Landa, V.; Mlejnek, P.; Miksik, I.; Dudova-Mothejzikova, K.; Pecina, P.; Vrbacky, M., et al. Direct linkage of mitochondrial genome variation to risk factors for type 2 diabetes in conplastic strains. Genome Res 2007, 17, 1319-1326, doi:10.1101/gr.6548207.

165. Balhara, B.; Alison, B.; Vehap, T.; Kyoung, L.Y.; Chad, C.; Ronald, K.C.; Elizabeth, P.M. Severe insulin resistance alters metabolism in mesenchymal progenitor cells. Endocrinology 2015, 156, 2039--2048, doi:10.1210/en.2014-1403.

166. Iovino, S.; M., B.A.; Laura, W.; Elizabeth, P.M.; Ronald, K.C. Myotubes derived from human-induced pluripotent stem cells mirror in vivo insulin resistance.

Proceedings of the National Academy of Sciences of the United States of America 2016, 10.1073/pnas.1525665113, doi:10.1073/pnas.1525665113.

167. Mori, E.; Junji, F.; Michio, N.; Kazuhiro, N.; Masaki, M.; Masakatsu, S.; Daisuke, T.; Toru, K.; Ken, E.; Takayuki, T., et al. Impaired adipogenic capacity in induced pluripotent stem cells from lipodystrophic patients with BSCL2 mutations.

Metabolism: Clinical and Experimental 2016, 10.1016/j.metabol.2015.12.015, doi:10.1016/j.metabol.2015.12.015.

168. Taura, D.; Noguchi, M.; Sone, M.; Hosoda, K.; Mori, E.; Okada, Y.; Takahashi, K.; Homma, K.; Oyamada, N.; Inuzuka, M., et al. Adipogenic differentiation of human induced pluripotent stem cells: comparison with that of human embryonic stem cells. FEBS Lett 2009, 583, 1029-1033, doi:10.1016/j.febslet.2009.02.031.

169. Noguchi, M.; Hosoda, K.; Nakane, M.; Mori, E.; Nakao, K.; Taura, D.; Yamamoto, Y.; Kusakabe, T.; Sone, M.; Sakurai, H., et al. In vitro characterization and engraftment of adipocytes derived from human induced pluripotent stem cells and embryonic stem cells. Stem Cells Dev 2013, 22, 2895-2905, doi:10.1089/scd.2013.0113.

170. Jozefczuk, J.; Karl, K.; Ramesh, U.; Frauke, H.; Samrina, R.; Suzanne, G.; Wasco, W.; Christian, R.; Andriani, D.; Christoph, W., et al. A systems biology approach to deciphering the etiology of steatosis employing patient-derived dermal fibroblasts and 
iPS cells. Frontiers in Physiology 2012, 10.3389/fphys.2012.00339, doi:10.3389/fphys.2012.00339.

171. Ali, G.; Elsayed, A.; Nandakumar, M.; Bashir, M.; Younis, I.; Abu Aqel, Y.; Memon, B.; Temanni, R.; Abubaker, F.; Taheri, S., et al. Keratinocytes derived from patientspecific induced pluripotent stem cells recapitulate the genetic signature of psoriasis disease. Stem Cells Dev 2020, 10.1089/scd.2019.0150, doi:10.1089/scd.2019.0150.

172. Soldner, F.; Rudolf, J. iPSC disease modeling. 2012; 10.1126/science.1227682.

173. Hockemeyer, D.; Rudolf, J. Induced pluripotent stem cells meet genome editing. 2016; 10.1016/j.stem.2016.04.013.

174. McKenna, A.; Hanna, M.; Banks, E.; Sivachenko, A.; Cibulskis, K.; Kernytsky, A.; Garimella, K.; Altshuler, D.; Gabriel, S.; Daly, M. The Genome Analysis Toolkit: a MapReduce framework for analyzing next-generation DNA sequencing data. Genome research 2010, 20, 1297-1303.

175. Yu, H.; Cowan, C.A. Minireview: Genome editing of human pluripotent stem cells for modeling metabolic disease. Molecular endocrinology 2016, 30, 575-586.

176. Merkle, F.T.; M., N.W.; David, S.; Eivind, V.; A., G.J.; Kristi, M.; Jackson, S.; F., S.A.; Kevin, E. Efficient CRISPR-Cas9-Mediated Generation of Knockin Human Pluripotent Stem Cells Lacking Undesired Mutations at the Targeted Locus. Cell Reports 2015, 10.1016/j.celrep.2015.04.007, doi:10.1016/j.celrep.2015.04.007.

177. Park, C.Y.; Jea, S.J.; Hwi, C.S.; R., L.D.; Hyun, P.I.; Wook, K.D. Modeling and correction of structural variations in patient-derived iPSCs using CRISPR/Cas9. Nature Protocols 2016, 10.1038/nprot.2016.129, doi:10.1038/nprot.2016.129. 